\title{
Temporal variability of carbon recycling in coastal sediments influenced by rivers: assessing the impact of flood inputs in the Rhône River prodelta
}

\author{
C. Cathalot ${ }^{1}$, C. Rabouille ${ }^{1}$, L. Pastor ${ }^{2}$, B. Deflandre ${ }^{2,3}$, E. Viollier ${ }^{2}$, R. Buscail ${ }^{4}$, A. Grémare ${ }^{3}$, C. Treignier ${ }^{1}$, and \\ A. Pruski ${ }^{5,6}$ \\ ${ }^{1}$ Laboratoire des Sciences du Climat et de l'Environnement, UMR 8212, CEA-CNRS/INSU-UVSQ Gif-sur-Yvette, France \\ ${ }^{2}$ Laboratoire de Geochimie des Eaux, IPGP \& Université Paris Diderot, Paris, France \\ ${ }^{3}$ Laboratoire Environnements et Paléoenvironnements Océaniques, Université Bordeaux 1, France \\ ${ }^{4}$ Centre de Formation et de Recherche sur l'Environnement Marin, Perpignan, France \\ ${ }^{5}$ LECOB, UPMC Univ Paris 06, FRE 3350, Observatoire Océanologique, Banyuls/mer, France \\ ${ }^{6}$ LECOB, CNRS, FRE 3350, Observatoire Océanologique, Banyuls/mer, France
}

Received: 9 October 2009 - Published in Biogeosciences Discuss.: 17 November 2009

Revised: 17 March 2010 - Accepted: 19 March 2010 - Published: 31 March 2010

\begin{abstract}
River deltas are particularly important in the marine carbon cycle as they represent the transition between terrestrial and marine carbon: linked to major burial zones, they are reprocessing zones where large carbon fluxes can be mineralized. In order to estimate this mineralization, sediment oxygen uptake rates were measured in continental shelf sediments and river prodelta over different seasons near the outlet of the Rhône River in the Mediterranean Sea. On a selected set of 10 stations in the river prodelta and nearby continental shelf, in situ diffusive oxygen uptake (DOU) and laboratory total oxygen uptake (TOU) measurements were performed in early spring and summer 2007 and late spring and winter 2008. In and ex situ DOU did not show any significant differences except for shallowest organic rich stations. Sediment DOU rates show highest values concentrated close to the river mouth (approx. $20 \mathrm{mmol} \mathrm{O}_{2} \mathrm{~m}^{-2} \mathrm{~d}^{-1}$ ) and decrease offshore to values around $4.5 \mathrm{mmol} \mathrm{O}_{2} \mathrm{~m}^{-2} \mathrm{~d}^{-1}$ with lowest gradients in a south west direction linked to the preferential transport of the finest riverine material. Core incubation TOU showed the same spatial pattern with an averaged TOU/DOU ratio of $1.2 \pm 0.4$. Temporal variations of sediment DOU over different sampling periods, spring summer and late fall, were limited and benthic mineralization rates presented a stable spatial pattern.
\end{abstract}

Correspondence to: C. Cathalot (cecile.cathalot@1sce.ipsl.fr)
A flood of the Rhône River occurred in June 2008 and delivered up to $30 \mathrm{~cm}$ of new soft muddy deposit. Immediately after this flood, sediment DOU rates close to the river mouth dropped from around $15-20 \mathrm{mmol} \mathrm{O}_{2} \mathrm{~m}^{-2} \mathrm{~d}^{-1}$ to values close to $10 \mathrm{mmol} \mathrm{O}_{2} \mathrm{~m}^{-2} \mathrm{~d}^{-1}$, in response to the deposition near the river outlet of low reactivity organic matter associated to fine material. Six months later, the oxygen distribution had relaxed back to its initial stage: the initial spatial distribution was found again underlining the active microbial degradation rates involved and the role of further deposits. These results highlight the immediate response of the sediment oxygen system to flood deposit and the rapid relaxation of this system towards its initial state (6 months or less) potentially linked to further deposits of reactive material.

\section{Introduction}

River dominated shelves represent a dynamic interface linking land and ocean biogeochemical cycles of relevant elements such as Organic Carbon (OC) (Hedges, 1992; Gattuso et al., 1998; McKee et al., 2004). They are productive areas sustained by high inputs of nutrients and terrestrial material (Dagg et al., 2004), characterized by a tight pelagic-benthic coupling and active benthic mineralization rates (Smith and Hollibaugh, 1993). Indeed, over $50 \%$ of all organic carbon burial in the ocean takes place in continental margins (Hedges and Keil, 1995). In addition, it is estimated that

Published by Copernicus Publications on behalf of the European Geosciences Union. 
up to $70 \%$ of the $0.15 \times 10^{15} \mathrm{gC}$ of particulate $\mathrm{OC}$ annually discharged from rivers to ocean is oxidized in these areas (Hedges et al., 1997; Burdige, 2005; Galy et al., 2007; Meybeck, 1982).

River inputs to the coastal ocean are highly variable over time, shifting from flood and high sediment supply to lowriver discharge (Wheatcroft and Borgeld, 2000). This variability causes a non-stationary OC deposition in deltas and prodeltas (Bentley and Nittrouer, 2003; McKee et al., 2004). Post-depositional processes such as physical (winnowing) and biological (bioturbation) reworking can also affect the organic matter reaching the sea floor in these environments (Rabouille et al., 2003). OC oxidation in sediments is coupled to the utilization of terminal electron acceptors: with the highest free energy yield, oxygen is first consumed by aerobic bacteria in the sedimentary column (Froelich et al., 1979). Oxygen distribution in sediments also reflects chemical reactions (oxidation of reduced species). Integrating benthic microbial respiration and reoxidation of anoxic reduced compounds, oxygen consumption by marine sediments is thus a good proxy to estimate benthic metabolism and OC mineralization rates and their variability over time and space in river dominated environments (Rabouille et al., 2003; Glud et al., 2000, 2003; Lansard et al., 2003; Cai et al., 1995). River flood may modify the sediment mineralization of organic matter by introducing large quantities of terrigeneous organic carbon with various reactivities and favour its preservation in shallow coastal environments (Leithold and Hope, 1999). Tesi et al. (2008) showed evidence of major changes in the biogeochemical composition and reactivity of sedimentary organic matter in a flood deposit in the Po River prodelta. Furthermore, the retention capacity of flood inputs in estuaries is variable: some estuaries may retain only $20 \%$ of the flood inputs in the innershore region (Lisitsyn, 1995; Sommerfield and Nittrouer, 1999), while other larger systems like the Atchafalaya River may act as efficient traps for flood inputs (Allison et al., 2000). It appears that (i) the response to flood events of continental margins at river outlets seems to be system-dependant and (ii) the parameters driving the sediment response are largely unknown. For instance, little is known about the partitioning between burial and recycling under normal and flood discharge rates regimes at the riversea interface. Given the high OC sequestration and oxidation potential of river dominated margins at a global scale (Blair et al., 2004; Burdige, 2005), it is therefore critical to assess the behaviour of the benthic system after a flood event, and especially the dynamics of its OC degradation activity.

Since the damming of the Nile, the Rhône River is the most important freshwater input of the Mediterranean Sea both in terms of water and particle discharges (Pont et al., 2002; Copin-Montegut, 1993). Its influence over the continental shelf of the Gulf of Lions has been widely documented (Monaco et al., 1999; De Madron et al., 2000, 2003; Sempere et al., 2000). Recently, Lansard et al. (2009) proposed a first snapshot of the oxygen uptake rates in the continental shelf sediments off the Rhône River mouth and observed a specific pattern with high sediment uptake rates near the outlet with an exponential gradient offshore.

Yet the evolution of this pattern of organic carbon recycling in sediments during the annual cycle and under flood conditions is completely unknown. In particular, floods are likely to play a major role in this dynamics since they can account up to $80 \%$ of the particles input from the Rhône River to the Mediterranean Sea (Antonelli et al., 2008). It has been proposed using a modelling approach that the Rhône River prodelta acts as a deposit centre for flood inputs (Ulses et al., 2008). Consequently, Rhône River flood events influence the recycling of organic matter in the river prodelta and alter the filtering capacity of river particulate inputs.

In this paper, we present oxygen uptake rates from a seasonal survey of the sediments in the Rhône River prodelta and adjacent shelf. The same stations were visited four times between April 2007 and December 2008, including a Rhône River flood period in June 2008. Transient evolution of the spatial pattern of the sediment oxygen uptake in the prodelta was investigated using in situ and laboratory measurements. As proxies of organic matter quality, OC and Chlorophyll $a$ (Chl $a$ ) contents in surface sediments also brought insights on the existing links between flood deposit lability, OC sediment degradation and the transitory processes involved between both. We discuss the effect of flood inputs and seasonal changes on the prodelta filtering capacity and the dynamics of oxygen and organic carbon in sediments after flood deposition.

\section{Material and methods}

\subsection{Study area}

The Gulf of Lions is a large continental shelf located in the NW Mediterranean Sea. The North Western Mediterranean current flows southwestward along the slope and imposes a general cyclonic circulation. The water column is seasonally stratified, but intense vertical mixing events, which induce major nutrient export, occur during strong regional winds outbursts (Millot, 1990; de Madron et al., 1999). The Gulf of Lions is a microtidal sea and the moderate wave-energy is swell-dominated. The Rhône River has a drainage basin of $97800 \mathrm{~km}^{2}$, a mean water flow of $1700 \mathrm{~m}^{3} \mathrm{~s}^{-1}$, and an annual particulate organic carbon discharge of $19.2 \pm 6 \times 10^{4} \mathrm{tC} / \mathrm{an}$ (Sempere et al., 2000). The Rhône River is thus the main source of freshwater, nutrients and organics for the Gulf of Lions (Sempere et al., 2000; Pont et al., 2002; De Madron et al., 2000). The hydrological regime of the Rhône River shows strong seasonal contrast with a large difference between low $\left(<500 \mathrm{~m}^{3} \mathrm{~s}^{-1}\right)$ and high $\left(>3000 \mathrm{~m}^{3} \mathrm{~s}^{-1}\right)$ water-discharge (Pont et al., 2002). Large amounts of terrestrial muddy sediments accumulate in the wide prodelta off the Rhône river mouth, extending then 


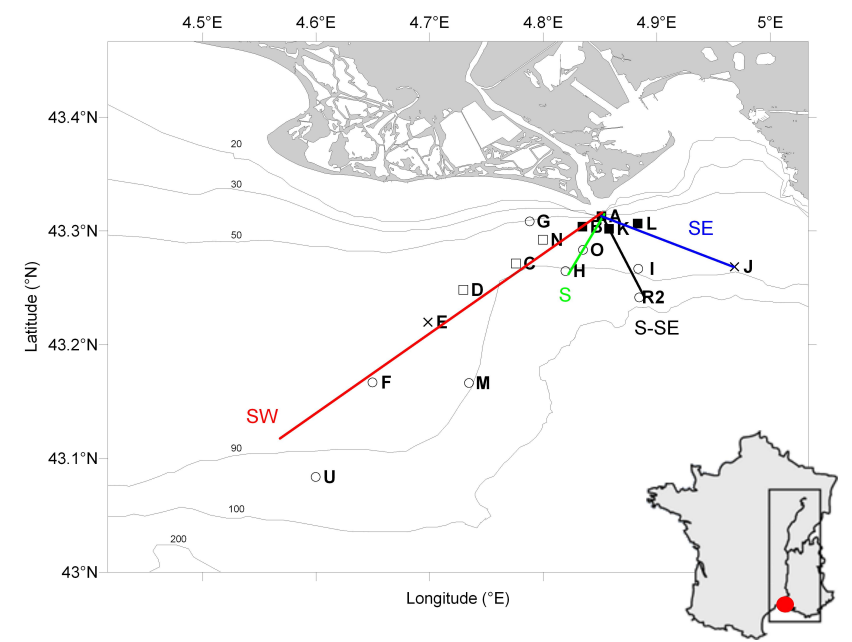

Fig. 1. Map of the Rhône delta indicating the locations of sampling stations. Black squares indicate stations sampled the four cruises. Empty squares indicate stations sampled three times. Black crosses indicate stations sampled twice. Empty circles indicate stations sampled once (April 2007).

the shoreline to $60 \mathrm{~m}$ depth (Friedrichs and Wright, 2004). Net sedimentation rates in the prodelta are up to $50 \mathrm{~cm} \mathrm{yr}^{-1}$ at the river mouth (Charmasson et al., 1998) and decrease rapidly offshore on the continental shelf, i.e. $0.2-0.6 \mathrm{~cm} \mathrm{yr}^{-1}$ at $20 \mathrm{~km}$ (Miralles et al., 2005). This sedimentation rates gradient defines the "prodelta" as the area of large sedimentation rates mostly above the $60 \mathrm{~m}$ bathymetric level and the "adjacent shelf" with greater water depths and lower sedimentation rates $\left(<1 \mathrm{~cm} \mathrm{y}^{-1}\right)$. The benthic macrofauna community in the area presents a low specific diversity compared to those of other soft bottom communities in the region. It is dominated in abundance by polychaetes mainly Sternaspis scutata. and Laonice cirrata, and by surface and subsurface deposit-feeders (Salen-Picard and Arlhac, 2002; Darnaude et al., 2004). The maximum richness in species is recorded at $70 \mathrm{~m}$ depth (Salen-Picard, 1982).

\subsection{Field sampling work and sampling procedures}

Sediment samples were collected during four cruises in April 2007, September 2007, June 2008 and December 2008 (Fig. 1). In April 2007, 16 stations were sampled off the Rhône river mouth in order to get a better estimate of the benthic mineralization rates in the Rhône prodelta. Key stations were then selected along onshore-offshore transects in water from 20 to $98 \mathrm{~m}$ depth. During the three other cruises, these selected stations were investigated again (Fig. 1). The June 2008 cruise took place while the Rhône River was experiencing an annual flood with a peak water discharge rate of $4156 \mathrm{~m}^{3} \mathrm{~s}^{-1}$. This flood event occurred after large amounts of precipitation over the Durance drainage basin (French Southern Alps), leading to a flood of this Rhône River trib-

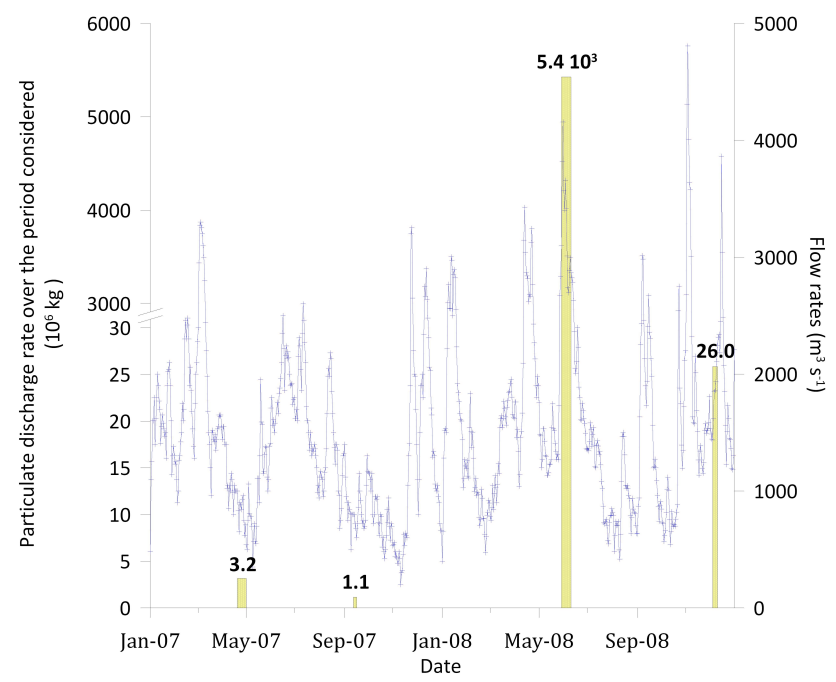

Fig. 2. Mean daily flow and particulate discharge rates of the Rhône River. The integrated SPM amount delivered during the sampling cruises period are indicated in yellow. Discharge and SPM data have been achieved in the courtesy of the CNR and the SORA in the workframe of a convention with IRSN in the EXTREMA ANR project.

utary with massive erosion of river banks leading to a suspended load of up to $3.7 \mathrm{~g} \mathrm{l}^{-1}$ (Fig. 2).

At each station in situ microelectrode measurements were performed as described in (Rabouille et al., 2003): briefly, 3$4 \mathrm{~h}$ deployments were performed at the sediment water interface using an autonomous microprofiling unit which records 5 oxygen microprofiles using Clark micro-electrodes and one resistivity microprofile. Sediment samples were collected with a multicorer MUC 8/100 (Oktopus $\mathrm{GmbH}$ ) that collect simultaneously eight P.C cores (I.D. $9.5 \mathrm{~cm}$ ) with a preserved sediment-water interface $(60 \mathrm{~cm}$ height with around $25 \mathrm{~cm}$ of overlying water and $35 \mathrm{~cm}$ of sediment). For micro-porosity measurements, cores were subsampled with a $50 \mathrm{ml}$ syringe and sliced at increasing depth intervals: $0.2 \mathrm{~cm}$ depth resolution for the first $\mathrm{cm}$ and $0.5 \mathrm{~cm}$ from 1 to $6 \mathrm{~cm}$ deep. Porosity $\phi$ was determined from the weight loss upon drying at $60{ }^{\circ} \mathrm{C}$ until complete dryness ( $\sim 2$ weeks) of sediment core segments of known weight and volume. Additional sediment cores with undisturbed surface structure were also collected for solid sediment sampling, cores incubation and microprofiling in the laboratory under in situ conditions. Sediments for organic carbon and Chl- $a$ analysis were collected and frozen on board ship immediately after sub-sampling within one hour after core collection. For core incubation and laboratory microprofiling, the cores were stored in a pool supplied by cooled sea water recirculation until they were brought to the shore and placed in a refrigerated box at in situ temperature. 
Bottom-water was sampled at $2 \mathrm{~m}$ above bottom by a Niskin bottle for determination of temperature and dissolved oxygen (Table 1).

In addition, a coring station $\left(43^{\circ} 18.420 \mathrm{~N}, 4^{\circ} 51.320 \mathrm{E}\right.$, water depth: $45 \mathrm{~m}$ ) was selected to monitor the evolution of flood deposits off the Rhône River mouth. Sediment cores were therefore collected four times at this station in June, September, October and December 2008. The cruise in December 2008 followed an annual flood that brought new material. Significant wave heights in 2008 in this area from June to December 2008 were acquired from the CANDHIS database of in situ wave height measurements.

For each cruise, immediately after sampling, a classical sedimentological inspection of the core was performed, describing the different visible layers. Sediments were then sectioned into slices and stored at $-20^{\circ} \mathrm{C}$ for further $\mathrm{OC}$ analyses. Vertical resolutions were: $0.5 \mathrm{~cm}$ in the first top centimetre, $1 \mathrm{~cm}$ down to $20 \mathrm{~cm}$, and $2 \mathrm{~cm}$ deeper in the core.

In June 2008, in order to describe the redox front in the flood deposit, redox potential measurements were performed on the core right after its retrieval. The redox potential (Eh in $\mathrm{mV}$ ) was obtained with a $\mathrm{pH} /$ redox meter (Knick apparatus and Ingold platinum electrode). Measurements were taken successively over the first $\mathrm{cm}$ and in the whole sedimentary column at $2 \mathrm{~cm}$ intervals (the P. C. core was equipped with a removable side panel).

\subsection{Organic carbon content analysis}

OC contents were analysed using milled, freeze-dried sediments. Surface OC content was determined on the $0-0.5 \mathrm{~cm}$ top layer of the sediment. Organic carbon concentrations were measured on homogeneised, precisely weighed subsamples in an automatic CN - analyser LECO 2000, after in cups acidification with $2 \mathrm{~N} \mathrm{HCl}$ (overnight, at $50^{\circ} \mathrm{C}$ ) in order to remove carbonates prior to the analyses of $\mathrm{OC}$ (Cauwet et al., 1990). The precision for OC was $2 \%$.

\subsection{Pigment analysis}

Surface sediments $(0-0.5 \mathrm{~cm}$ layer) were rapidly thawed and $100 \mathrm{mg}$ were extracted overnight in $5 \mathrm{ml}$ of acetone at $5^{\circ} \mathrm{C}$ in the dark. Adjustment was made for sediment water content to obtain a final acetone degree of $90 \%$. The fluorescence of the sediment extracts was measured on a LS 55 spectrofluorimeter (Perkin Elmer Inc., USA) according to the method developed by Neveux and Lantoine (1993). Uncertainty on the pigments content was lower than $1 \%$. For each station, the analyses were performed on three cores and in triplicates (i.e. 9 independent extracts). Data are expressed as weight per gram dry sediment.

\subsection{Grain size measurement}

Sediment granulometry was assessed using a Malvern Mastersizer 2000 laser microgranulometer. Grain size is given as the $\mathrm{d}(0.5)$, which corresponds to the median of the size distribution based on the equivalent spherical volume diameters.

\subsection{Microelectrode measurements}

The $200 \mu \mathrm{m}$ resolution $\mathrm{O}_{2}$ and resistivity in situ profiles were obtained by a benthic microprofiler (Unisense ${ }^{\circledR}$ ) equipped with 4-5 $\mathrm{O}_{2}$ microelectrodes and 1 resistivity sensor. The profiling unit was mounted on an autonomous tripodal frame.

Ex situ measurements of $\mathrm{O}_{2}$ microprofiles were performed in a thermostated bath maintained at in situ sampling temperature. Up to 15 steady-state $\mathrm{O}_{2}$ microprofiles $(50-100 \mu \mathrm{m}$ resolution) were completed within $6 \mathrm{~h}$ after sampling. Conservation of overlying water oxygenation was achieved by a soft bubbling system.

Dissolved oxygen concentration was measured by oxygen microelectrodes (Unisense ${ }^{\circledR}$ ) provided with a built-in reference and an internal guard cathode (Revsbech, 1989). The $\mathrm{O}_{2}$ microsensors had tip outer diameters of $50-100 \mu \mathrm{m}$, a stirring sensitivity of $<1 \%$, a $90 \%$ response time $<10$ s, and less than $2 \%$ per hour current drift. The electrode signals were recorded in the overlying-water before and after each profile to assess the stability of the measurements. We used a linear calibration for the microelectrodes, between the bottom water oxygen content estimated by Winkler titration (Grasshoff et al., 1983) and the anoxic zone of the sediment.

The location of the sediment-water interface relative to the in situ oxygen profiles was determined from $\mathrm{O}_{2}$ microprofiles. We used the classical method which consists in assigning the interface location to a break in the oxygen concentration gradient. The observed change of slope is due to the increased diffusion coefficient in the sediment compared to the diffusive boundary layer (DBL) (Jorgensen and Revsbech, 1985; Revsbech, 1989; Sweerts et al., 1989). In some profiles, the slope break was not clearly visible: they rather displayed a steady increase of the slope towards a maximum within the first millimeter below the initial concentration decrease. In these cases, we adopted the position of this maximum gradient as the sediment-water interface. Oxygen penetration depth was determined from the $\mathrm{O}_{2}$ profile and was assigned to the depth where the microelectrode signal reached the zero current.

Resistivity measurements were carried out with an electrode similar to the one described by Andrews and Bennett (1981). Four thin parallel wires were buried in a matrix of epoxy, with only their tips in electrical contact with seawater. The resistivity sensor has a rectangular section of $10 \times 3 \mathrm{~mm}$ and is edged at the lower end. Recordings were made at $200 \mu \mathrm{m}$ as for the oxygen but the pertinent resolution is certainly around $1 \mathrm{~mm}$ due to the shape of the sensor (Rabouille et al., 2003; Andrews and Bennett, 1981). Voltage outputs were calibrated to resistivity with standard $\mathrm{KCl}$ solutions, and the resistivity recordings were converted to inverse formation factor values by the formulation of Berner (1980):

$F^{-1}=R_{b w} / R_{z}$ 
Table 1. Temporal variations of Rhône River prodelta bottom water and sediment properties. $m$ coefficient from Archie's law used for porosity assessment, mean sediment grain size diameter $(\mu \mathrm{m})$ and chloropigments $(\mathrm{Chl} b / \mathrm{Chl} a$ and Pheo $a$ ) are detailed for each station.

\begin{tabular}{|c|c|c|c|c|c|c|c|c|c|c|c|c|}
\hline Stations & $\begin{array}{l}\text { Lat. } \\
\left({ }^{\circ} \mathrm{N}\right)\end{array}$ & $\begin{array}{l}\text { Long. } \\
\left({ }^{\circ} \mathrm{N}\right)\end{array}$ & $\begin{array}{r}\text { Depth e } \\
(\mathrm{m})\end{array}$ & $\begin{array}{r}\text { Distance } \\
(\mathrm{km})\end{array}$ & Cruise & $\begin{array}{l}\text { Tbw } \\
\left({ }^{\circ} \mathrm{C}\right)\end{array}$ & $\begin{array}{r}{\left[\mathrm{O}_{2}\right] b w} \\
(\mu \mathrm{M})\end{array}$ & $\begin{array}{r}m \\
\text { coeff }\end{array}$ & $\begin{array}{r}\text { Mean } \\
\text { diameter }\end{array}$ & $\begin{array}{r}\% \text { Corg in } \\
\text { surficial sediment }\end{array}$ & $\begin{array}{l}\text { Chl } b / \\
\text { Chl } a\end{array}$ & $\begin{array}{r}\text { Pheo } a \\
\left(\mu \mathrm{gg}^{-1}\right)\end{array}$ \\
\hline $\mathbf{A}$ & $43^{\circ} 18^{\prime} 47^{\prime \prime}$ & $4^{\circ} 51^{\prime} 4^{\prime \prime}$ & 24 & 1.9 & $\begin{array}{c}\text { Apr-07 } \\
\text { Sep-07 } \\
\text { Jun-08 } \\
\text { Dec-08 }\end{array}$ & $\begin{array}{l}14.9 \\
17.7 \\
16.8 \\
14.8\end{array}$ & $\begin{array}{l}259 \\
244 \\
238 \\
237\end{array}$ & $\begin{array}{l}2.74 \\
1.99 \\
2.17 \\
1.97\end{array}$ & $\begin{array}{r}37.40 \\
- \\
6.74 \\
-\end{array}$ & $\begin{array}{l}1.99 \\
1.40 \\
1.13 \\
1.22\end{array}$ & $\begin{array}{r}14.2 \\
17.3 \\
9.3 \\
26.4\end{array}$ & $\begin{array}{r}20.5 \pm 1.5 \\
11.0 \pm 0.8 \\
4.6 \pm 0.6 \\
6.5 \pm 3.4\end{array}$ \\
\hline B & $43^{\circ} 18^{\prime} 14^{\prime \prime}$ & $4^{\circ} 50^{\prime} 4^{\prime \prime}$ & 54 & 3.0 & $\begin{array}{r}\text { Apr-07 } \\
\text { Sep-07 } \\
\text { Jun-08 } \\
\text { Dec-08 }\end{array}$ & $\begin{array}{l}14.6 \\
14.5 \\
14.0 \\
14.7\end{array}$ & $\begin{array}{l}249 \\
214 \\
223 \\
234\end{array}$ & $\begin{array}{l}2.42 \\
2.42 \\
2.45 \\
2.64\end{array}$ & $\begin{array}{r}14.83 \\
- \\
23.87 \\
-\end{array}$ & $\begin{array}{l}1.61 \\
1.37 \\
1.75 \\
1.96\end{array}$ & $\begin{array}{r}10.2 \\
7.1 \\
8.1 \\
20.9\end{array}$ & $\begin{array}{l}21.8 \pm 1.2 \\
12.5 \pm 0.3 \\
17.7 \pm 1.1 \\
17.5 \pm 1.0\end{array}$ \\
\hline C & $43^{\circ} 16^{\prime} 17^{\prime \prime}$ & $4^{\circ} 46^{\prime} 33^{\prime \prime}$ & 76 & 8.6 & $\begin{array}{r}\text { Apr-07 } \\
\text { Jun-08 } \\
\text { Dec-08 }\end{array}$ & $\begin{array}{l}14.5 \\
14.7 \\
14.7\end{array}$ & $\begin{array}{l}243 \\
239 \\
235\end{array}$ & $\begin{array}{l}2.29 \\
1.80 \\
2.40\end{array}$ & $\begin{array}{r}11.38 \\
14.51 \\
-\end{array}$ & $\begin{array}{l}1.25 \\
1.16 \\
1.49\end{array}$ & $\begin{array}{l}3.6 \\
5.3 \\
0.0\end{array}$ & $\begin{array}{r}12.2 \pm 1.2 \\
8.4 \pm 0.2 \\
17.5 \pm 1.0\end{array}$ \\
\hline D & $43^{\circ} 14^{\prime} 54^{\prime \prime}$ & $4^{\circ} 43^{\prime} 46^{\prime \prime}$ & 74 & 13.0 & $\begin{array}{r}\text { Apr-07 } \\
\text { Sep-07 } \\
\text { Jun-08 } \\
\text { Dec-08 }\end{array}$ & $\begin{array}{r}14.3 \\
15 \\
14.0 \\
14.8\end{array}$ & $\begin{array}{l}244 \\
217 \\
226 \\
237\end{array}$ & $\begin{array}{l}1.43 \\
1.46 \\
2.31\end{array}$ & $\begin{array}{r}10.45 \\
- \\
12.10 \\
-\end{array}$ & $\begin{array}{l}1.05 \\
0.99 \\
1.00 \\
1.16\end{array}$ & $\begin{array}{l}0.0 \\
0.0 \\
0.0 \\
0.0\end{array}$ & $\begin{array}{r}13.8 \pm 2.8 \\
8.8 \pm 0.7 \\
7.5 \pm 3.9 \\
13.3 \pm 0.7\end{array}$ \\
\hline $\mathbf{E}$ & $43^{\circ} 13^{\prime} 12^{\prime \prime}$ & $4^{\circ} 41^{\prime} 54^{\prime \prime}$ & 75 & 17.0 & $\begin{array}{r}\text { Apr-07 } \\
\text { Jun-08 }\end{array}$ & $\begin{array}{l}14.2 \\
15.6\end{array}$ & $\begin{array}{l}245 \\
245\end{array}$ & $\begin{array}{l}2.09 \\
2.18\end{array}$ & $\begin{array}{r}9.43 \\
15.02\end{array}$ & 1.07 & $\begin{array}{l}0.0 \\
0.0\end{array}$ & $\begin{array}{l}13.4 \pm 0.7 \\
10.3 \pm 1.0\end{array}$ \\
\hline $\mathbf{F}$ & $43^{\circ} 10^{\prime} 1^{\prime \prime}$ & $4^{\circ} 41^{\prime} 59^{\prime \prime}$ & 78 & 21.6 & $\begin{array}{l}\text { Apr-07 } \\
\text { Jun-08 }\end{array}$ & $\begin{array}{l}14.2 \\
14.7\end{array}$ & $\begin{array}{l}257 \\
242\end{array}$ & 2.55 & $\begin{array}{r}9.15 \\
-\end{array}$ & $\begin{array}{l}1.04 \\
1.03\end{array}$ & 0.0 & $12.6 \pm 1.8$ \\
\hline $\mathbf{U}$ & $43^{\circ} 5^{\prime} 2^{\prime \prime}$ & $4^{\circ} 35^{\prime} 58^{\prime \prime}$ & 90 & 33.8 & Jun-08 & 13.8 & 231 & 2.58 & 14.27 & 0.82 & 0.0 & $6.7 \pm 2.5$ \\
\hline G & $43^{\circ} 18^{\prime} 30^{\prime \prime}$ & $4^{\circ} 47^{\prime} 17^{\prime \prime}$ & 47 & 5.2 & Apr-07 & 14.8 & 249 & 2.33 & 17.38 & - & 5.5 & $14.9 \pm 0.2$ \\
\hline H & $43^{\circ} 15^{\prime} 53^{\prime \prime}$ & $4^{\circ} 49^{\prime} 10^{\prime \prime}$ & 86 & 7.5 & $\begin{array}{l}\text { Apr-07 } \\
\text { Sep-07 } \\
\text { Jun-08 }\end{array}$ & $\begin{array}{l}14.5 \\
14.9 \\
14.0\end{array}$ & $\begin{array}{l}236 \\
202 \\
245\end{array}$ & $\begin{array}{l}2.28 \\
1.35 \\
2.71\end{array}$ & $\begin{array}{r}9.99 \\
- \\
14.15\end{array}$ & $\begin{array}{l}1.17 \\
1.00 \\
1.11\end{array}$ & $\begin{array}{l}0.0 \\
0.0 \\
0.0\end{array}$ & $\begin{array}{r}11.6 \pm 1.6 \\
9.8 \pm 0.2 \\
10.3 \pm 1.4\end{array}$ \\
\hline I & $43^{\circ} 16^{\prime} 0^{\prime \prime}$ & $4^{\circ} 53^{\prime} 1^{\prime \prime}$ & 89 & 7.7 & $\begin{array}{c}\text { Apr-07 } \\
\text { Jun-08 }\end{array}$ & $\begin{array}{l}15.1 \\
15.9\end{array}$ & $\begin{array}{l}231 \\
238\end{array}$ & $\begin{array}{l}2.56 \\
2.64\end{array}$ & $\begin{array}{l}10.70 \\
16.26\end{array}$ & $\begin{array}{l}1.03 \\
1.12\end{array}$ & $\begin{array}{l}0.0 \\
0.0\end{array}$ & $\begin{array}{l}11.3 \pm 0.7 \\
10.5 \pm 0.7\end{array}$ \\
\hline $\mathbf{J}$ & $43^{\circ} 16^{\prime} 7^{\prime \prime}$ & $4^{\circ} 58^{\prime} 6^{\prime \prime}$ & 86 & 12.1 & $\begin{array}{r}\text { Apr-07 } \\
\text { Jun-08 }\end{array}$ & $\begin{array}{l}14.1 \\
14.0\end{array}$ & $\begin{array}{l}243 \\
227\end{array}$ & $\begin{array}{l}2.42 \\
2.36\end{array}$ & $\begin{array}{l}11.59 \\
14.27\end{array}$ & $\begin{array}{l}0.99 \\
1.01\end{array}$ & $\begin{array}{l}0.0 \\
0.0\end{array}$ & $\begin{array}{r}9.4 \pm 0.6 \\
11.8 \pm 6.9\end{array}$ \\
\hline $\mathbf{K}$ & $43^{\circ} 18^{\prime} 7^{\prime \prime}$ & $4^{\circ} 51^{\prime} 29^{\prime \prime}$ & 62 & 3.3 & $\begin{array}{r}\text { Apr-07 } \\
\text { Sep-07 } \\
\text { Jun-08 } \\
\text { Dec-08 }\end{array}$ & $\begin{array}{l}14.6 \\
18.2 \\
16.8 \\
14.7\end{array}$ & $\begin{array}{l}249 \\
241 \\
240 \\
235\end{array}$ & $\begin{array}{l}2.21 \\
2.05 \\
2.01 \\
2.65\end{array}$ & $\begin{array}{r}17.49 \\
- \\
11.98 \\
-\end{array}$ & $\begin{array}{l}1.79 \\
1.39 \\
1.02 \\
1.62\end{array}$ & $\begin{array}{r}10.1 \\
6.7 \\
7.6 \\
20.7\end{array}$ & $\begin{array}{r}17.2 \pm 1.0 \\
13.0 \pm 0.3 \\
9.2 \pm 1.9 \\
10.5 \pm 0.1\end{array}$ \\
\hline $\mathbf{L}$ & $43^{\circ} 18^{\prime} 24^{\prime \prime}$ & $4^{\circ} 52^{\prime} 59^{\prime \prime}$ & 62 & 4.0 & $\begin{array}{r}\text { Apr-07 } \\
\text { Sep-07 } \\
\text { Jun-08 } \\
\text { Dec-08 }\end{array}$ & $\begin{array}{l}14.3 \\
18.0 \\
16.7 \\
15.0\end{array}$ & $\begin{array}{l}247 \\
238 \\
229 \\
233\end{array}$ & $\begin{array}{l}2.85 \\
2.03 \\
3.02 \\
1.95\end{array}$ & $\begin{array}{r}13.56 \\
- \\
9.10 \\
-\end{array}$ & $\begin{array}{l}1.51 \\
1.26 \\
1.06 \\
1.11\end{array}$ & $\begin{array}{r}8.9 \\
11.3 \\
6.1 \\
29.7\end{array}$ & $\begin{array}{r}18.4 \pm 4.0 \\
13.9 \pm 0.9 \\
8.7 \pm 1.4 \\
8.9 \pm 2.5\end{array}$ \\
\hline $\mathbf{M}$ & $43^{\circ} 9^{\prime} 59^{\prime \prime}$ & $4^{\circ} 44^{\prime} 4^{\prime \prime}$ & 91 & 20.3 & Apr-07 & 14.1 & 241 & 2.42 & 9.89 & - & 0.0 & $16.1 \pm 1.2$ \\
\hline $\mathbf{N}$ & $43^{\circ} 17^{\prime} 33^{\prime \prime}$ & $4^{\circ} 47^{\prime} 59^{\prime \prime}$ & 67 & 5.5 & $\begin{array}{l}\text { Apr-07 } \\
\text { Sep-07 } \\
\text { Jun-08 }\end{array}$ & $\begin{array}{l}14.5 \\
14.5 \\
16.3\end{array}$ & $\begin{array}{l}253 \\
217 \\
240\end{array}$ & $\begin{array}{l}1.79 \\
1.75 \\
2.22\end{array}$ & $\begin{array}{r}14.01 \\
- \\
10.65\end{array}$ & $\begin{array}{l}1.43 \\
1.20 \\
1.00\end{array}$ & $\begin{array}{l}6.9 \\
0.0 \\
6.2\end{array}$ & $\begin{array}{l}14.3 \pm 0.2 \\
11.5 \pm 0.7 \\
12.3 \pm 6.6\end{array}$ \\
\hline $\mathbf{O}$ & $43^{\circ} 17^{\prime} 0^{\prime \prime}$ & $4^{\circ} 50^{\prime} 6^{\prime \prime}$ & 79 & 5.2 & Apr-07 & 14.4 & 251 & 1.94 & 11.06 & 1.20 & 1.2 & $14.0 \pm 0.9$ \\
\hline $\mathbf{R 2}$ & $43^{\circ} 14^{\prime} 30^{\prime \prime}$ & $4^{\circ} 53^{\prime} 4^{\prime \prime}$ & 98 & 10.3 & Apr-07 & 14.1 & 242 & 2.40 & 9.55 & - & 0.0 & $9.8 \pm 1.4$ \\
\hline
\end{tabular}


Where $R_{b w}$ is the average resistivity in the bottom water and $R_{z}$ is the mean resistivity at given depth $z$.

We calculated then a porosity profile by converting $F^{-1}$ values using the empirical Archie's relation:

$F^{-1}=\phi^{m}$

Where $\phi$ is the porosity and $m$ is an experimental factor usually ranging from to 2 to 3 . $m$ was determined for each station as corresponding to the best least square fit to the measured porosity profile (through an Microsoft Excel® solver routine).

\subsection{Sediment diffusive oxygen fluxes calculations}

Sediment oxygen consumption rates were estimated from $\mathrm{O}_{2}$ microprofiles by two ways. Diffusive oxygen uptake (DOU) was calculated from $\mathrm{O}_{2}$ concentration gradients at the sediment-water interface by using the 1-D Fick's first law of diffusion: $\mathrm{DOU}=\varphi D_{s}\left[\frac{\mathrm{dO}_{2}}{\mathrm{~d} x}\right]_{x=0}$ where $\phi$ is the porosity, $D_{s}$ is the $\mathrm{O}_{2}$ diffusion coefficient within the sediment and $\left[\frac{\mathrm{dO}_{2}}{\mathrm{~d} x}\right]_{x=0}$ is the oxygen gradient just below the sedimentwater interface (estimated from the profiles). $D_{s}$ was estimated as $D s=\frac{D_{002}}{1+3(1-\varphi)}$ (Iversen and Jorgensen, 1993). $D_{0_{\mathrm{O}_{2}}}$ is the molecular diffusion coefficient of $\mathrm{O}_{2}\left(\mathrm{~cm}^{2} \mathrm{~s}^{-1}\right)$ at in situ temperature, salinity and hydrostatic pressure and was evaluated using tables from Broecker and Peng (1974).

We also used the numerical model PROFILE (Berg et al., 1998), which calculates the consumption rates with depth by adjusting a calculated oxygen profile to the observed one. It allowed us to determine the location of oxygen production and oxygen consumption layers, the extent of these zones, and the resulting fluxes across the sediment-water interface. The two boundary conditions used for the calculations correspond to the zero oxygen concentration and flux at the bottom of the oxic zone.

\subsection{Sediment core incubation and total oxygen uptake measurements}

Immediately after retrieval, 3 sediment cores with undisturbed interface were selected per station and placed in a refrigerated box at in situ temperature back to the laboratory. Once sealed, overlying water was kept homogenised by a rotating floating magnet fixed to the upper core cap. Dark incubations started within $6 \mathrm{~h}$ after sampling. Every 2-4h, $50 \mathrm{ml}$ of the overlying water was sampled and replaced with the same volume of filtered bottom water (Denis et al., 2001; Hulth et al., 1997) We determined the oxygen concentration in the overlying water of each core and the filtered bottom water by Winkler titration (Grasshoff et al., 1983). Sampling intervals and incubation duration were adjusted so that oxygen concentration in the overlying water did not decrease by more than $20-30 \%$ of the initial concentration. TOU was calculated from concentration change of oxygen in the overlying water with incubation time, after correction had been made for input of replacement water. This approach allowed the determination of TOU with only a small deviation from the ambient bottom water concentrations in the overlying water.

\subsection{Statistical calculation}

Non parametric Wilcoxon signed rank tests were used to assess statistical differences between in situ vs. ex situ DOU and OPD. These tests were performed on the mean in and ex situ DOU and OPD recorded for any combination of cruises and stations.

Significance of temporal changes in in situ DOU at each station was assessed using non parametric Kruskal-Wallis ANOVAs (when stations had been sampled more than twice), or Mann and Whitney U tests (when stations had been sampled only twice).

A two way analysis of variance (ANOVA) was carried out to test for temporal and depth differences in sedimentary OC content among sampling periods (June, September, October and December) and deposit layers (sediment depth).

\section{Results}

\subsection{Porosity: cores measurements and estimation from $F^{-1}$}

At all stations, porosity decreases gradually with depth from $0.85-0.9$ for the top $2 \mathrm{~mm}$ to a value ranging between $0.62-$ 0.77 at $6 \mathrm{~cm}$ depth (Fig. 3). These profiles display relatively high values of porosity consistent with data reported by Reimers et al. (1992). Most stations show constant porosity profile with time, except station A located at the river outlet. This station also displays a large change in grain size between April 2007 and June 2008, i.e. normal to flood condition (mean $\emptyset=6.7-37.4 \mu \mathrm{m}$; Table 1 ). The porosity derived from $F^{-1}$ factor through the power law $F^{-1}=\phi^{-m}$ match the measured values and thus allow the estimation of $\mathrm{m}$ (Fig. 3). Indeed, on average $r^{2}$ is $0.9939 \mathrm{~m}$ values displayed an average of $2.2 \pm 0.4$ (Table 1). The observed variations were not correlated to the mean diameter $\left(r^{2}=0.06\right.$, $n=28$ ).

\subsection{Surface sediment carbon content}

Organic Carbon (OC) content of surficial sediments in the Rhône river prodelta ranged from $0.99 \%$ to $1.99 \%$ d.w. (Table 1; Fig. 4). Stations away from the river outlet (D, E, F, H, I, J) displayed a homogeneous and stable organic content of $1.04 \pm 0.08 \%$ (i.e. Coefficient of variation C.V. of only $8.1 \%$ ). At all cruises except June 2008, stations close to the river outlet showed higher content around $1.5-2 \%$, stations $\mathrm{A}$ and $\mathrm{B}$ being the more enriched. OC content decreased 

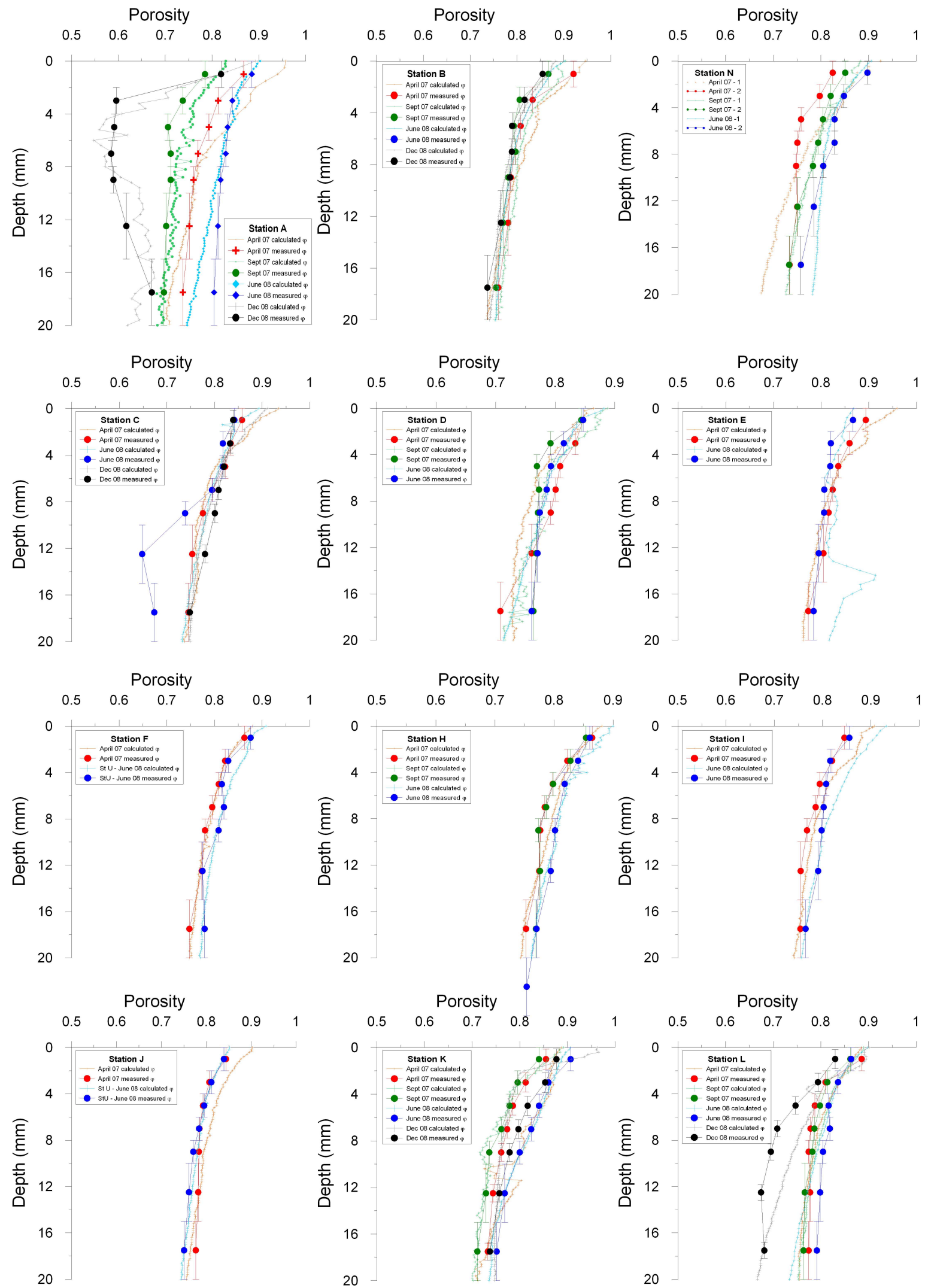

Fig. 3. Porosity profiles for all stations during all cruises. Data points indicate measured values while thin curves represent the fitted profiles based on resistivity measurements and Archie's law (see text for details). 


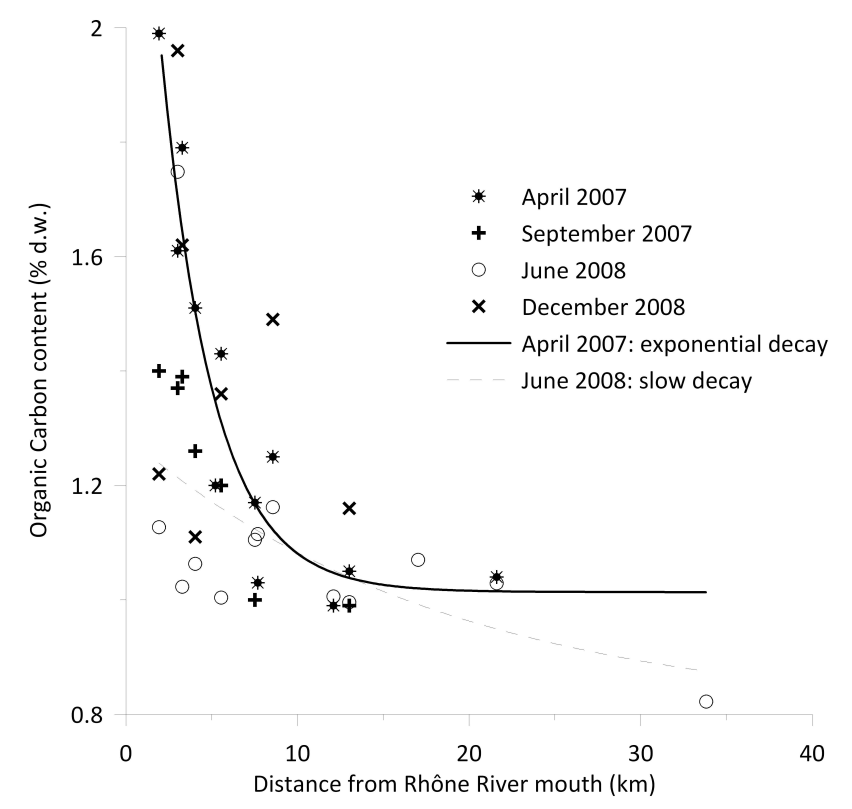

Fig. 4. Organic carbon (OC) content in surficial sediments as a function of distance from the river outlet for April 07 (black stars *), September 07 (black crosses $\$$ ), June 08 cruises (empty circles O) and December 08 (black diagonal crosses $\boldsymbol{*}$ ). Exponential decays of OC with distance in April 2007 and June 2008 are plotted to highlight the trends.

rapidly with distance from the river outlet in the prodelta (first $10 \mathrm{~km}$ ) and more slowly in the adjacent shelf (Fig. 4; solid line regression). Conversely, OC content in June 2008 was homogeneous over all the prodelta: all stations ("offshore" stations as nearshore ones) presented the same low content of $1.04 \pm 0.08 \%$.

\subsection{Surface sediment pigment content}

Chlorophyll $a$ (Chl $a$ ), Chlorophyll $b$ (Chl $b$ ) and Pheophytin $a$ (Pheo $a$ ) content of surficial sediments in the Rhône River prodelta are available for all cruises. Chl $a$ contents displayed an exponential decrease with distance from the river mouth $\left(r^{2}>0.7178, p<0.01\right)$ with highest values located in the prodelta (Fig. 5). Chl $a$ sediment contents were significantly lower in June 2008 than the April 2007, September 2007 and December 2008 values pooled together (test: Mann-Whitney, $p<0.05)$. In April, September and December, Chl $a$ content were around $4.75 \pm 2.84 \mu \mathrm{g} \mathrm{g}^{-1}$ d.w. near the river outlet (stations A, B) decreasing to low values about $1.67 \pm 0.83 \mu \mathrm{g} \mathrm{g}^{-1}$ d.w. offshore. In June 2008, however, during the flood event, the pattern was different with values in stations $A$ and B around $3.32 \pm 0.68 \mu \mathrm{g} \mathrm{g}^{-1}$ d.w. and lower concentration in shelf sediments with an average of $1.08 \pm 0.91 \mu \mathrm{g} \mathrm{g}^{-1}$ d.w. (Fig. 5). Chl $b$ was detected only near the river mouth and Pheo a presented higher contents in the most proximal stations (Table 1).

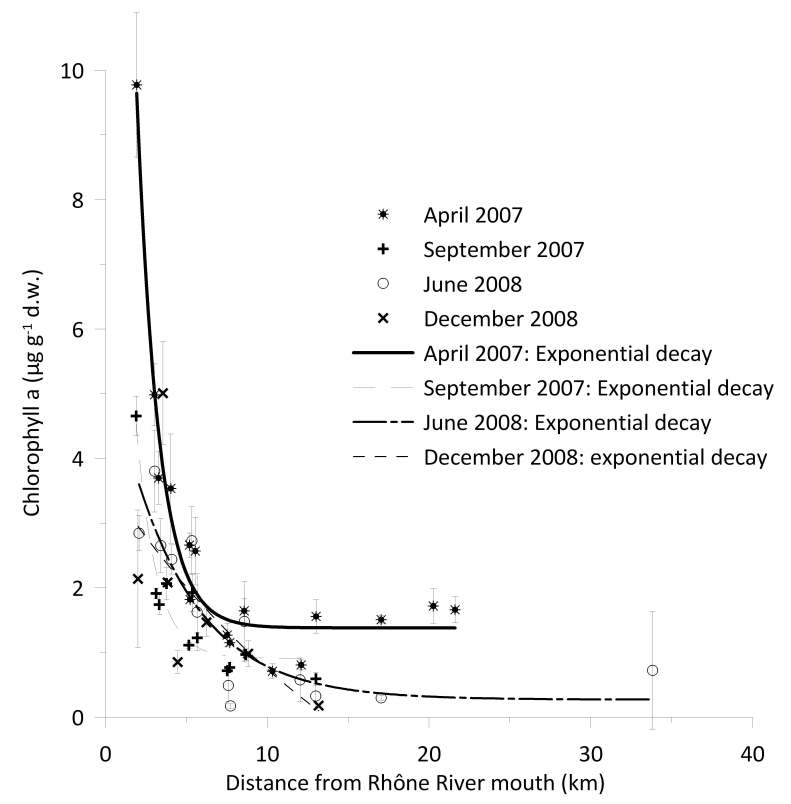

Fig. 5. Surface sediments Chl $a$ contents as a function of distance from the river outlet: * April 2007, + September 2007, ○ June 2008 and $\boldsymbol{*}$ December 2008.

\subsection{Sediment oxygen uptake}

In April 2007, the microprofiler was deployed at 16 stations, an extension of the area previously covered (Lansard et al., 2009): 8 and 12 of these stations were resampled respectively in September 2007 and June 2008. Finally in December 2008, only 6 stations close to the Rhône River mouth were sampled because of meteorological conditions. All oxygen profiles showed decreasing $\mathrm{O}_{2}$ concentrations through a diffusive boundary layer of about $0.2-2.2 \mathrm{~mm}$ above the sediment-water interface (Fig. 6). Below, $\mathrm{O}_{2}$ concentrations decrease rapidly with steep gradients, the steepness depending on the station. The oxygen penetration depth (OPD) into the sediment ranges from $1.6 \pm 0.3 \mathrm{~mm}$ in front of the Rhône River mouth to $12.7 \pm 1.7 \mathrm{~mm}$ about $30 \mathrm{~km}$ south-westward (Table 2). There was no statistical difference between in situ and ex situ OPD $(p>0.05)$. Generally OPD increased with distance from the Rhône River mouth. Apart from the June 2008 cruise corresponding to a river flood event, all OPD on the SW transect showed linear increase with distance from station A, i.e. near the river mouth $\left(r^{2}>0.883\right)$. Near the Rhône River mouth (stations A, B, K), OPD were statistically different in June 2008 compared to the other cruises. The other stations did not display any differences in OPD between cruises.

Positive fluxes of $\mathrm{O}_{2}$ (from the overlying water into the sediment) were measured in all investigated stations. Total Oxygen Uptake rates measured by core incubations had average values ranging from $\sim 16 \mathrm{mmo} \mathrm{O}_{2} \mathrm{~m}^{-2} \mathrm{~d}^{-1}$ close to the river mouth (stations $\mathrm{A}$ and $\mathrm{B}$ ) to $\sim 3 \mathrm{mmol} \mathrm{O}_{2} \mathrm{~m}^{-2} \mathrm{~d}^{-1}$ 
Table 2. Temporal variations of Oxygen Uptake Rates in the sediments of the Rhône River prodelta (means \pm SD). OPD stands for oxygen penetration depth; DOU for Diffusive Oxygen Uptake and TOU for Total Oxygen Uptake.

\begin{tabular}{|c|c|c|c|c|c|c|c|c|c|c|c|}
\hline \multirow[b]{2}{*}{ Stations } & \multirow[b]{2}{*}{ Cruise } & \multicolumn{2}{|c|}{$\begin{array}{c}n=\text { number of replicated } \\
\mathrm{O}_{2} \text { profiles }\end{array}$} & \multicolumn{3}{|c|}{$\begin{array}{l}\mathrm{OPD} \\
(\mathrm{mm})\end{array}$} & \multicolumn{3}{|c|}{$\begin{array}{c}\text { DOU } \\
\left(\mathrm{mmolO}_{2} \mathrm{~m}^{-2} \mathrm{~d}^{-1}\right)\end{array}$} & \multirow{2}{*}{$\begin{array}{c}\text { TOU } \\
\left(\mathrm{mmolO}_{2} \mathrm{~m}^{-2} \mathrm{~d}^{-1}\right)\end{array}$} & \multirow[b]{2}{*}{ TOU/DOL } \\
\hline & & in situ & ex situ & in situ & ex situ & C.V. (\%) & in situ & ex situ & C.V. (\%) & & \\
\hline \multirow[t]{4}{*}{$\mathbf{A}$} & Apr-07 & 4 & 5 & $1.4 \pm 0.2$ & $2.0 \pm 0.3$ & $18 \%$ & $21.5 \pm 3.9$ & $14.4 \pm 2.1$ & $15 \%$ & $15.6 \pm 5.0$ & $1.1 \pm 0.5$ \\
\hline & Sep-07 & 5 & - & $1.7 \pm 0.1$ & - & $10 \%$ & $15.3 \pm 1.5$ & - & & - & - \\
\hline & Jun-08 & 5 & 7 & $5.8 \pm 0.8$ & $3.5 \pm 0.4$ & $34 \%$ & $9.2 \pm 3.1$ & $9.4 \pm 1.6$ & $17 \%$ & $9.8 \pm 1.4$ & $1.0 \pm 0.3$ \\
\hline & Dec-08 & 4 & 8 & $1.6 \pm 0.3$ & $2.6 \pm 0.2$ & $17 \%$ & $16.6 \pm 2.9$ & $9.3 \pm 1.2$ & $13 \%$ & $11.9 \pm 1.5$ & $1.3 \pm 0.3$ \\
\hline \multirow[t]{4}{*}{ B } & Apr-07 & 4 & 6 & $2.2 \pm 0.3$ & $2.5 \pm 0.5$ & $14 \%$ & $15.7 \pm 2.1$ & $12.1 \pm 2.4$ & $20 \%$ & $15.9 \pm 3.6$ & $1.3 \pm 0.4$ \\
\hline & Sep-07 & 5 & - & $2.1 \pm 0.3$ & - & $36 \%$ & $14.7 \pm 5.3$ & - & & - & - \\
\hline & Jun-08 & 5 & 11 & $3.3 \pm 0.6$ & $2.8 \pm 0.2$ & $26 \%$ & $10.6 \pm 2.8$ & $9.9 \pm 0.7$ & $7 \%$ & $16.5 \pm 1.4$ & $1.7 \pm 0.2$ \\
\hline & Dec-08 & 5 & 10 & $1.8 \pm 0.4$ & $3.1 \pm 0.1$ & $44 \%$ & $17.5 \pm 7.6$ & $8.5 \pm 1.1$ & $13 \%$ & $10.8 \pm 3.0$ & $1.3 \pm 0.4$ \\
\hline \multirow[t]{3}{*}{ C } & Apr-07 & 4 & 7 & $4.7 \pm 1.5$ & $4.2 \pm 0.3$ & $31 \%$ & $10.3 \pm 3.2$ & $7.6 \pm 1.2$ & $15 \%$ & $7.8 \pm 0.6$ & $1.0 \pm 0.2$ \\
\hline & Jun-08 & 5 & 6 & $3.4 \pm 0.7$ & $3.4 \pm 0.7$ & $36 \%$ & $9.3 \pm 3.3$ & $7.2 \pm 2.5$ & $35 \%$ & $10.0 \pm 1.3$ & $1.4 \pm 0.5$ \\
\hline & Dec-08 & 5 & 9 & $5.4 \pm 0.8$ & $6.1 \pm 0.4$ & $40 \%$ & $6.8 \pm 2.8$ & $5.0 \pm 0.3$ & $5 \%$ & $4.4 \pm 0.4$ & $0.9 \pm 0.1$ \\
\hline \multirow[t]{4}{*}{ D } & Apr-07 & 4 & - & $6.4 \pm 1.3$ & - & $49 \%$ & $6.3 \pm 3.1$ & - & & - & - \\
\hline & Sep-07 & 5 & - & $8.2 \pm 1.2$ & - & $6 \%$ & $4.5 \pm 0.3$ & - & & - & - \\
\hline & Jun-08 & 5 & 12 & $5.5 \pm 0.4$ & $4.9 \pm 0.7$ & $47 \%$ & $8.0 \pm 3.7$ & $6.0 \pm 1.0$ & $17 \%$ & $6.0 \pm 1.0$ & $1.0 \pm 0.3$ \\
\hline & Dec-08 & - & 12 & - & $8.4 \pm 1.1$ & & - & $4.6 \pm 0.9$ & & $3.2-1.5$ & $0.7-0.7$ \\
\hline \multirow[t]{2}{*}{$\mathbf{E}$} & Apr-07 & 4 & - & $5.2 \pm 0.7$ & - & $20 \%$ & $8.4 \pm 1.7$ & - & & - & - \\
\hline & Jun-08 & 5 & - & $4.3 \pm 0.8$ & - & $21 \%$ & $8.5 \pm 1.8$ & - & & - & - \\
\hline \multirow[t]{2}{*}{$\mathbf{F}$} & Apr-07 & 4 & 8 & $9.7 \pm 2.1$ & $7.8 \pm 1.1$ & $12 \%$ & $5.3 \pm 0.7$ & $5.3 \pm 0.7$ & $13 \%$ & $7.0 \pm 2.0$ & $1.3 \pm 0.4$ \\
\hline & Jun-08 & - & 12 & - & $6.9 \pm 1.2$ & & _- & $4.7 \pm 1.1$ & $23 \%$ & $5.6 \pm 0.3$ & $1.2 \pm 0.3$ \\
\hline $\mathbf{U}$ & Jun-08 & 5 & - & $12.7 \pm 1.7$ & - & $35 \%$ & $4.8 \pm 1.7$ & - & & - & - \\
\hline G & Apr-07 & 4 & - & $3.6 \pm 0.2$ & - & $22 \%$ & $9.7 \pm 2.2$ & - & & - & - \\
\hline \multirow[t]{3}{*}{ H } & Apr-07 & 4 & - & $4.8 \pm 0.9$ & - & $13 \%$ & $7.2 \pm 0.9$ & - & & - & - \\
\hline & Sep-07 & 5 & - & $6.5 \pm 0.9$ & - & $43 \%$ & $5.1 \pm 2.2$ & - & & - & - \\
\hline & Jun-08 & 5 & 10 & $3.0 \pm 0.6$ & $4.8 \pm 0.5$ & $15 \%$ & $7.6 \pm 1.1$ & $6.8 \pm 1.4$ & $21 \%$ & $11.9 \pm 6.1$ & $1.8 \pm 0.7$ \\
\hline \multirow[t]{2}{*}{ I } & Apr-07 & 4 & 6 & $6.7 \pm 0.3$ & $4.3 \pm 0.7$ & $18 \%$ & $4.6 \pm 0.8$ & $6.3 \pm 1.1$ & $18 \%$ & $10.1 \pm 0.9$ & $1.6 \pm 0.3$ \\
\hline & Jun-08 & 5 & 9 & $5.6 \pm 2.6$ & $4.7 \pm 0.3$ & $56 \%$ & $8.7 \pm 4.9$ & $7.7 \pm 1.6$ & $21 \%$ & $7.7 \pm 2.4$ & $1.0 \pm 0.5$ \\
\hline \multirow[t]{2}{*}{$\mathbf{J}$} & Apr-07 & 4 & 3 & $7.5 \pm 2.2$ & $8.7 \pm 0.7$ & $46 \%$ & $7.2 \pm 3.3$ & $4.4 \pm 0.8$ & $19 \%$ & $9.6 \pm 2.0$ & $2.2 \pm 0.4$ \\
\hline & Jun-08 & 5 & 6 & $8.3 \pm 0.3$ & $7.9 \pm 1.4$ & $42 \%$ & $6.2 \pm 2.6$ & $4.9 \pm 0.5$ & $10 \%$ & $4.4 \pm 1.0$ & $0.9 \pm 0.3$ \\
\hline \multirow[t]{4}{*}{$\mathbf{K}$} & Apr-07 & 4 & 8 & $2.6 \pm 0.7$ & $2.8 \pm 0.3$ & $21 \%$ & $10.8 \pm 2.2$ & $11.0 \pm 2.3$ & $21 \%$ & $10.2 \pm 2.2$ & $0.9 \pm 0.4$ \\
\hline & Sep-07 & 5 & - & $3.2 \pm 0.6$ & - & $10 \%$ & $19.9 \pm 2.1$ & - & & - & - \\
\hline & Jun-08 & 5 & 7 & $6.0 \pm 1.1$ & - & $44 \%$ & $8.8 \pm 3.9$ & - & & - & - \\
\hline & Dec-08 & 5 & 7 & $2.2 \pm 0.7$ & $3.0 \pm 0.2$ & $44 \%$ & $12.5 \pm 5.5$ & $8.6 \pm 0.7$ & $8 \%$ & $6.1 \pm 2.8$ & $0.7 \pm 0.5$ \\
\hline \multirow[t]{4}{*}{$\mathbf{L}$} & Apr-07 & 3 & 5 & $4.9 \pm 2.1$ & $3.5 \pm 0.3$ & $55 \%$ & $7.0 \pm 3.9$ & $7.2 \pm 0.6$ & $8 \%$ & $11.8 \pm 9.8$ & $1.6 \pm 0.9$ \\
\hline & Sep-07 & 5 & - & $3.0 \pm 0.8$ & - & $26 \%$ & $9.9 \pm 2.6$ & - & & - & - \\
\hline & Jun-08 & 5 & - & $3.4 \pm 0.8$ & - & $40 \%$ & $11.3 \pm 4.5$ & - & & - & - \\
\hline & Dec-08 & 5 & 10 & $4.0 \pm 1.1$ & $4.3 \pm 0.4$ & $68 \%$ & $8.9 \pm 6.1$ & $6.0 \pm 1.2$ & $20 \%$ & $2.3 \pm 0.2$ & $0.4 \pm 0.3$ \\
\hline $\mathbf{M}$ & Apr-07 & 4 & - & $9.4 \pm 2.7$ & - & $50 \%$ & $6.9 \pm 3.5$ & - & & - & - \\
\hline \multirow[t]{3}{*}{$\mathbf{N}$} & Apr-07 & 4 & 5 & $3.3 \pm 0.6$ & $3.1 \pm 0.4$ & $12 \%$ & $9.5 \pm 1.2$ & $10.1 \pm 1.2$ & $12 \%$ & $11.4 \pm 2.6$ & $1.1 \pm 0.4$ \\
\hline & Sep-07 & 5 & - & $4.9 \pm 1.1$ & - & $14 \%$ & $6.6 \pm 0.9$ & - & & - & - \\
\hline & Jun-08 & 5 & - & $3.8 \pm 0.6$ & - & $20 \%$ & $9.2 \pm 1.9$ & - & & - & - \\
\hline O & Apr-07 & 4 & - & $4.7 \pm 0.3$ & - & $11 \%$ & $8.1 \pm 0.9$ & - & & - & - \\
\hline $\mathbf{R 2}$ & Apr-07 & 4 & - & $7.1 \pm 1.8$ & - & $49 \%$ & $7.0 \pm 3.4$ & - & & - & - \\
\hline
\end{tabular}

further offshore in the South-East direction. Table 2 displays DOU/TOU ratios for each station. Generally they were not significantly different from 1 except for stations far offshore as $\mathbf{J}$ and $\mathbf{I}$, which displayed a value around 2 during some cruises, indicating substantial contribution of non-diffusive processes such as bioturbation or irrigation (Table 2).
The DOU rates were calculated using both Fick's law at the sediment water interface and the PROFILE software taking $D_{S}=\frac{D_{0}}{1+3(1-\phi)}$ (data not shown). Differences between DOU from both calculations (PROFILE and interface gradient) did not exceed $20 \%$, thus confirming the reliability of the estimation. The average in situ Diffusive Oxygen Uptake (DOU) rates ranged from approx. $20 \mathrm{mmol} \mathrm{O}_{2} \mathrm{~m}^{-2} \mathrm{~d}^{-1}$ 


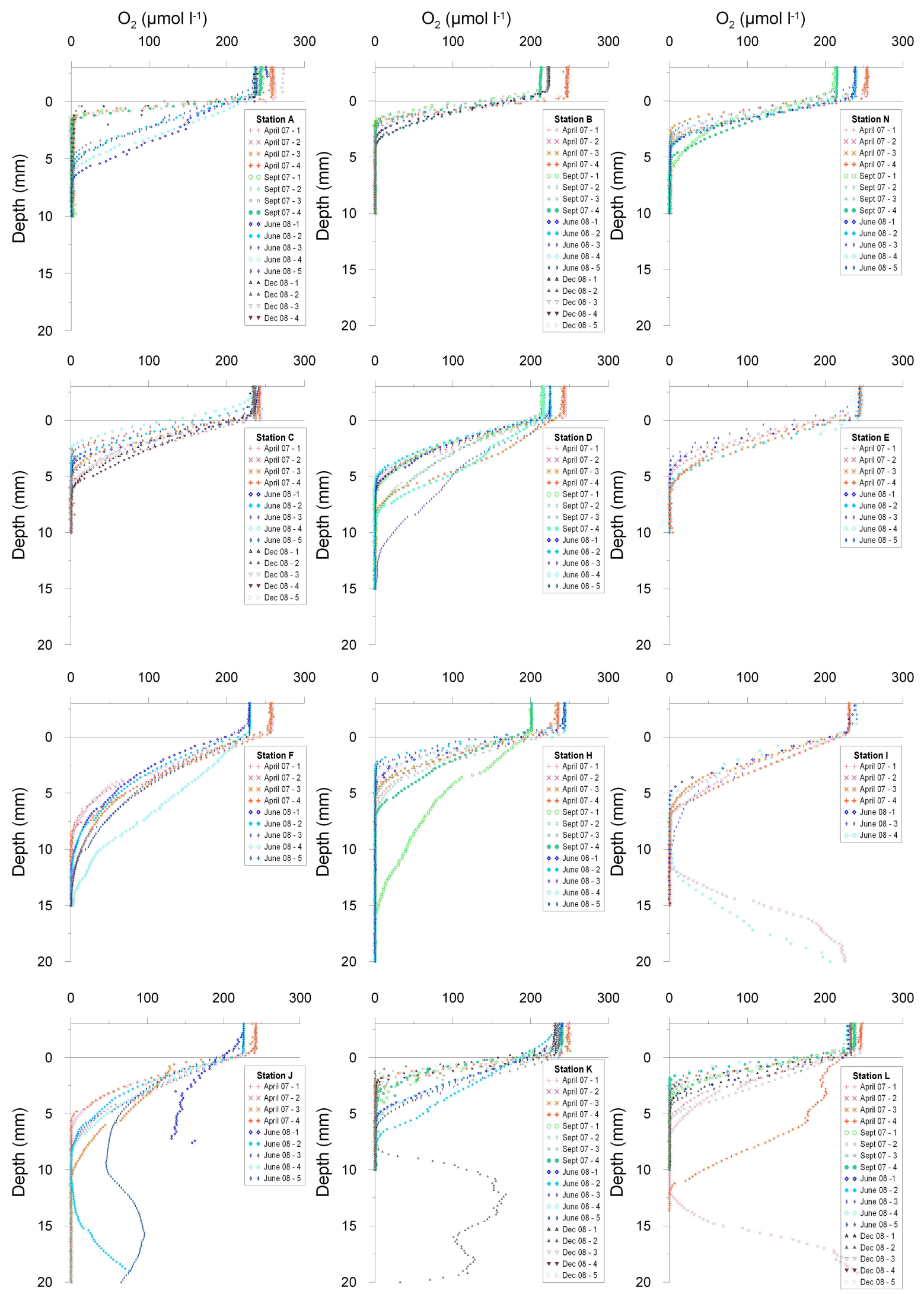

Fig. 6. In situ Oxygen microprofiles in the sediment at all station investigated for April 2007 (red), September 2007 (green), June 2008 (Blue) and December 2008 (brown). 
Table 3. Comparison of in situ DOU rates between cruises Results of non-parametric statistical tests (Mann-Whitney when degrees of freedom $=1$ and Kruskal Wallis when $\geq 2$ ). Bold indicate significant differences.

\begin{tabular}{lcc}
\hline Stations & $\begin{array}{c}\text { In situ DOU: } \\
\text { comparison over cruises } p\end{array}$ & $\begin{array}{c}\text { Degree of } \\
\text { freedom }\end{array}$ \\
\hline A & $\mathbf{0 . 0 0 4 2}$ & 3 \\
B & 0.2035 & 3 \\
C & 0.2241 & 2 \\
D & 0.2268 & 2 \\
E & 0.5480 & 1 \\
F & 0.2780 & 1 \\
H & 0.1661 & 2 \\
I & 0.0950 & 1 \\
J & 0.4520 & 1 \\
K & $\mathbf{0 . 0 4 2 0}$ & 3 \\
L & 0.1131 & 3 \\
N & $0.06687^{*}$ & 2 \\
\hline
\end{tabular}

* Significant for threshold $\alpha=0.1$.

near the Rhône river mouth (stations $\mathrm{A}, \mathrm{B}, \mathrm{K}$ ) to approx. $4.5 \mathrm{mmol} \mathrm{O}_{2} \mathrm{~m}^{-2} \mathrm{~d}^{-1}$ at station on the middle shelf (stations I, J, F, U). DOU rates from cores presented the same distribution pattern with high fluxes at the Rhône river outlet and similar lower values as going offshore. Ex situ and in situ DOU rates were significantly different $(p<0.001$, signed rank test). Nevertheless, this difference seems to be mainly driven by the larger variance of the in situ DOU rates compared to the ex situ values. Highest differences between in situ and ex situ values were recorded at stations $\mathrm{A}, \mathrm{B}, \mathrm{K}$ and $\mathrm{L}$, i.e. stations located close to the river outlet. At these stations, ex situ values were significantly lower $(p<0.05$, signed rank test performed on stations A, B, K and L), whereas the two techniques give similar DOU rates at the other sites $(p>0.05$, signed rank test performed on all stations except A, B, K and L).

Except for station A and $\mathrm{K}, \mathrm{O}_{2}$ fluxes were not statistically different from one cruise to another (Table 3). They displayed the same spatial pattern with intense consumption near the Rhône river mouth and lower DOUs over the shelf (Fig. 7a). This tendency is clearly displayed when plotting the DOU rates as a function of distance to station A for the April 2007 cruise (Fig. 8). Under normal discharge rate conditions, the negative gradient in sediment oxygen uptake rates was generally smoother in the South West direction than along the other transects (S, S-SE and SE).

This general pattern was observed at every cruise except during the flood event in June 2008 (Fig. 7b). In contrast, the DOU rates obtained in June 2008 were much lower in the prodelta and homogeneous over the shelf up to a distance of $10 \mathrm{~km}$ from the outlet ( $p>0.05$; Fig. 7b). As the SW direction is the main dispersion direction, plotting the South-

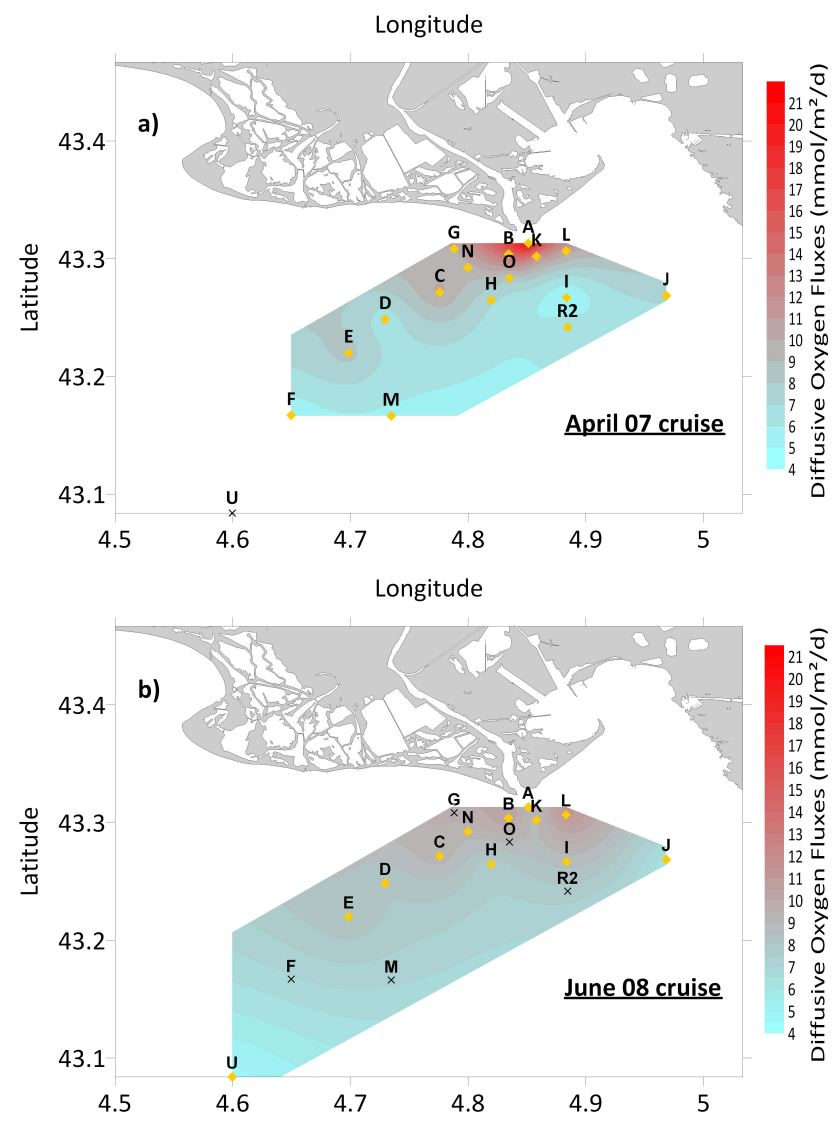

Fig. 7. Spatial distribution of Diffusive Oxygen Uptakes Rates in sediments during April 2007 "normal condition" (a) and June 2008 "flood condition"(b). $\times$ indicate stations which were not sampled during this cruise.

West transect for all cruises reveals different gradient over time (Fig. 9). A clear slope break appears on the chart between the SW gradients near shore and off shore. The linear regression applied to the data thus allows the estimation of the DOU gradients over the prodelta which are similar for all cruises except June 2008 corresponding to the flood.

The PROFILE program on station A was used to determine the location of oxygen consumption in June 2008. It appeared that the consumption was low and spread all over the oxic layer, or located at the bottom of the oxygen profile. On average at station $\mathrm{A}$, the maximum consumption rates were $910^{-2} \mathrm{mmol} \mathrm{O}_{2} \mathrm{~L}^{-1} \mathrm{~h}^{-1}$ compared to $1.1 \pm 0.3 \mathrm{mmol} \mathrm{O}_{2} \mathrm{~L}^{-1} \mathrm{~h}^{-1}$ for normal conditions.

\subsection{Monitoring of the flood deposit}

Figure 10 displays the evolution of the flood deposit of June 2008 at the dedicated station located $2.7 \mathrm{~km}$ of the river mouth at a depth of $45 \mathrm{~m}$.

Based on the visual sedimentological description, it appears that the June 2008 flood deposit corresponds to the 


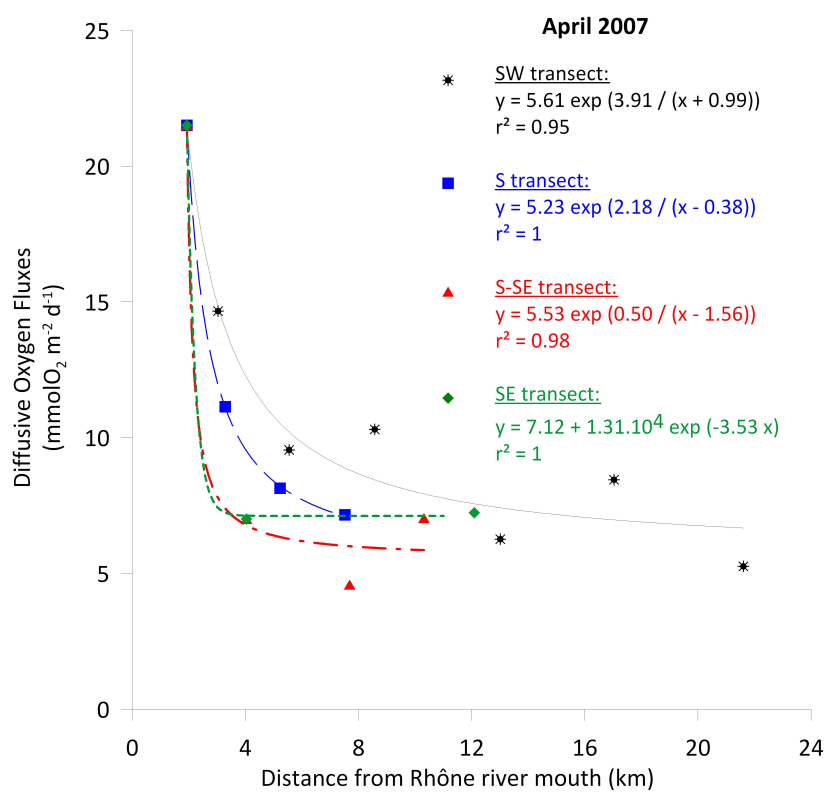

Fig. 8. Decrease of DOU rates with distance from station A in April 2007 for different transects: * South West SW (stations A, B, N, C, D, E, F, U - black plain line), $\mathbf{D}$ South S (stations A, K, O, H - blue dashed line), $\Delta$ South-South-East S-SE (stations A, L, I, R2 - red dotted-dashed line) and South-East SE (stations A, L, J - green dotted line).

homogoneous and fluid clear grey mud. This layer constitutes the $\sim 28 \mathrm{~cm}$ top layer of the September and October 2008 cores. At this station in December 2008, on the contrary, this layer is present only below $20 \mathrm{~cm}$ deep in the sediment. Above, from the surface until the June 2008 flood layer, the sediment consists of $5 \mathrm{~cm}$ of a very fluid dark mud, $10 \mathrm{~cm}$ of a soft dark gray mud and $5 \mathrm{~cm}$ of dark grey mud mixed with sand (Fig. 10, right panel).

The OC content of the flood deposit is lower than the average OC content in the prodelta sediments (Fig. 10). In average in the first $28 \mathrm{~cm}$, OC contents are stable from June to September and October $(1.2 \pm 0.1 \%$ d.w., $1.2 \pm 0.1 \%$ d.w., $1.4 \pm 0.4 \%$ d.w., $p>0.05, F=2.6, d f=1)$. This content increases in December 2008 up to $2.2 \pm 1.5 \%$ d.w. which is statistically different from the three previous cores $(p<0.001, F=8.05, d f=2)$.

The redox potential profile in the June 2008 flood deposit presents positive values from the surface until $10 \mathrm{~cm}$ depth. Then anoxic processes become prominent with negative values down to $28-30 \mathrm{~cm}$. In the underlying ochre mud $(30-$ $32 \mathrm{~cm}$ ), the redox potential rises again, reflecting thus the location of the old sediment-water interface. Below this former interface, the dark muds with strong $\mathrm{H}_{2} \mathrm{~S}$ smell are even more reduced than the bottom part of the flood deposit.

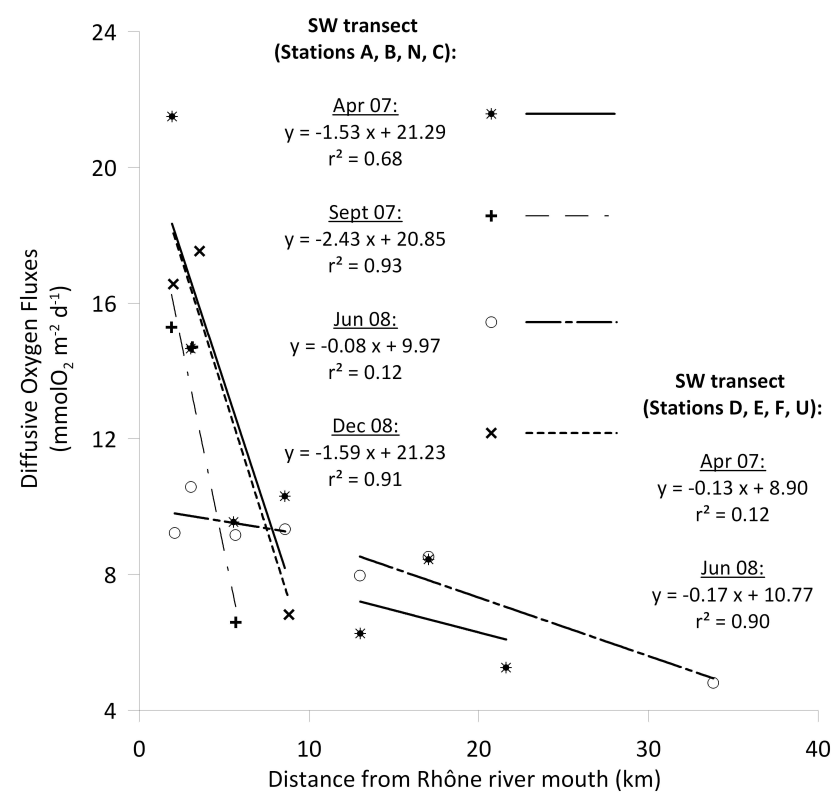

Fig. 9. Temporal variations of South West DOU gradient. Stations close to the river outlet (A, B, N, C - left part of the chart) were separated from stations offshore (D, E, F, U - right part of the chart) due to the clear slope break.

\section{Discussion}

\subsection{Comparison of in situ and ex situ diffusive oxygen uptake rates}

Differences between the in situ and ex situ techniques were not homogeneous among our station set. Indeed, the greatest differences were recorded close to the river outlet at stations $\mathrm{A}, \mathrm{B}, \mathrm{K}$ and $\mathrm{L}$, whereas stations located further away on the shelf displayed similar DOU rates for both techniques. For stations in the prodelta DOU rates were 30-40\% lower than the in situ ones.

Such underestimation of the in situ rates by laboratorydetermined DOU has already been observed in shallow coastal environments (Glud et al., 2003) and can result from several factors: natural variability in sediment porosity, spatial heterogeneity of the mineralization at the station scale, variations in the thickness of the DBL layer between the two techniques.

Indeed, the DBL thickness is linked to the level of turbulence in the water column and influences $\mathrm{O}_{2}$ fluxes at the sediment water interface by changing the diffusion path length to the thin oxic sediment layer (Berner, 1980; Lorke et al., 2003; Kelly-Gerreyn et al., 2005; Roy et al., 2002; Brand et al., 2009). A thicker DBL due to difficulties in mimicking in situ turbulences can cause a decreased oxygen availability and result in an overall decrease of sediment oxygen uptake (Glud et al., 2007). Nevertheless, in situ and ex situ DBL thicknesses were similar (data not shown). It is therefore 


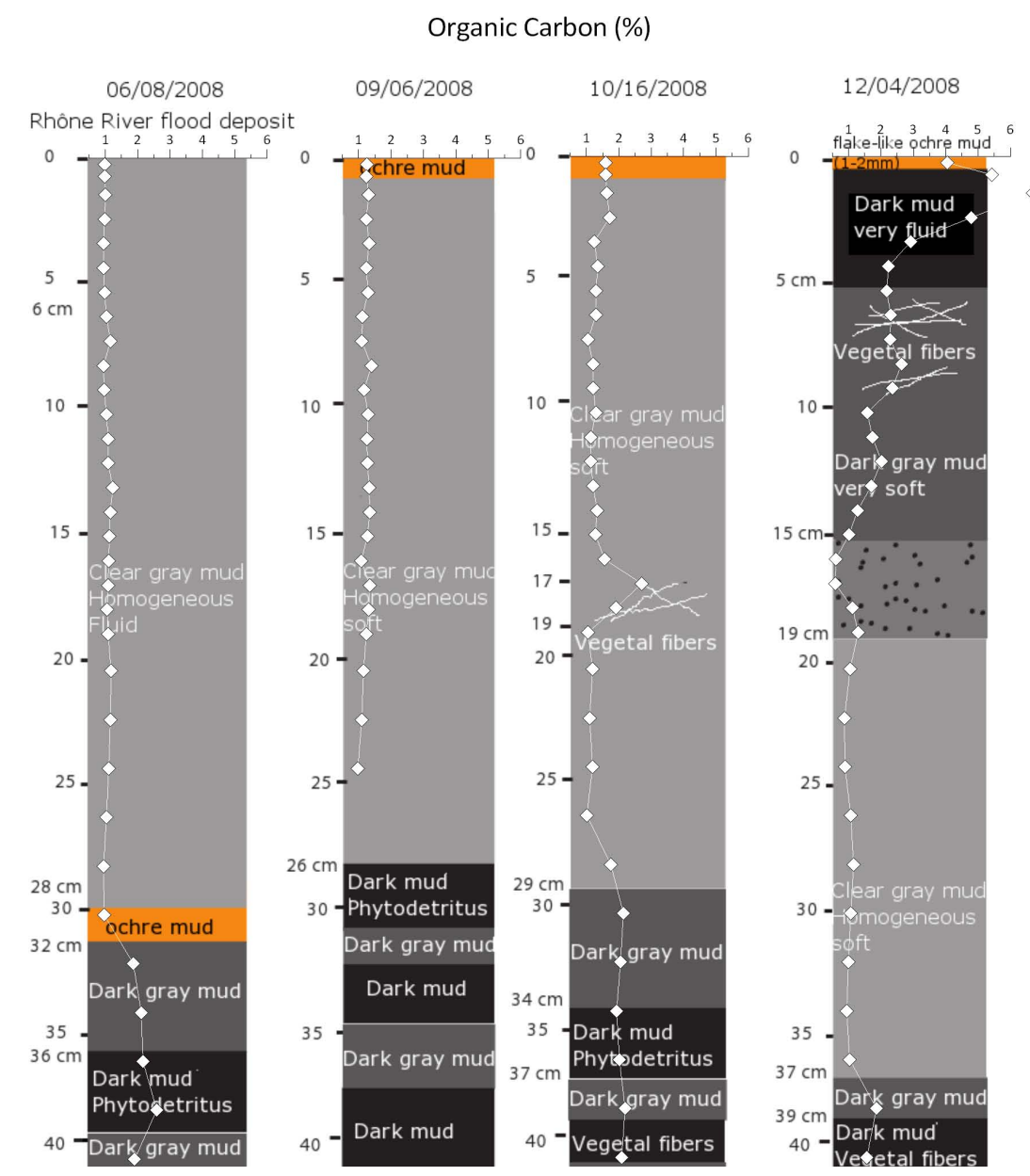

Fig. 10. The evolution of the flood deposit of June 2008 at a depth of $45 \mathrm{~m}, 2.7 \mathrm{~km}$ of the river mouth: sedimentological observations and OC content in June, September, October and December 2008.

likely that the soft stirring performed $5 \mathrm{~cm}$ above the SWI during ex situ profiling was adequate to reproduce in situ conditions and differences between the two techniques most likely result from other processes.

Variance was higher for in situ DOU than for ex situ ones. This suggests that, in our case, in situ and ex situ techniques provide different representations of the natural spatial variability of the sediment. Spatial variability in river-influenced coastal environments is a common and important feature regarding benthic carbon degradation and sediment oxygen uptake rate distribution (Accornero et al., 2003; Rabouille et al., 2003; Lansard et al., 2003; Hopkinson et al., 2001).

At the smaller scale, natural local spatial heterogeneity in such a river-dominated coastal shelf can also lead to differences in DOU rates. Indeed, variations in particulate inputs and episodic resuspension events together with the deposition of macro organic debris can alter the microtopography and the organic matter distribution on the seafloor, creating spatial heterogeneity down to centimetre scales such as hotspots of organic matter (Rabouille et al., 2003). Such param- eters are important controlling factors on benthic degradation activity and would therefore affect the small-scale variability of sediment oxygen uptakes. Hence, the highest differences between in situ and ex situ DOU rates observed in the Rhône River prodelta in addition to the higher variances of in situ values suggest that ex situ and in situ profiles did not capture the same small-scale spatial heterogeneity. First, we can not exclude the bias induced by the operator: the core selection in order to get interfaces as undisturbed as possible could lead to exclusion of fauna which creates heterogeneity in the sediment (Glud et al., 1998) Second, the number of profiles performed per station in each technique $(\sim 5$ in situ; $\sim 10$ ex situ) is too limited to provide an exhaustive representation of the small scale variability of the system. For such a purpose, in situ oxygen profiles measurements, with a high replicate number, are necessary, especially in variable environments such as river prodeltas. However, our in situ measurements did capture some of the small scale variability of the sediment. Thus, at the prodelta scale, they provide a fair estimate of diffusive oxygen fluxes in the sediments. 


\subsection{Spatial and temporal distribution of benthic mineralization in the Rhône River prodelta}

\subsubsection{Spatial variability in sediment oxygen uptake}

$\mathrm{O}_{2}$ uptake rates measured out of the June 2008 flood period display a spatial distribution pattern (Fig. 7a) consistent with the one previously described by Lansard et al. (2009). High sediment oxygen consumption were found in a radius of $8 \mathrm{~km}$ from the vicinity of the Rhône river mouth with values from 10 to $20 \mathrm{mmol} \mathrm{O}_{2} \mathrm{~m}^{-2} \mathrm{~d}^{-1}$; these rates decreasing offshore to values around $5 \mathrm{mmol} \mathrm{O}_{2} \mathrm{~m}^{-2} \mathrm{~d}^{-1}$ (stations $\mathrm{F}, \mathrm{I}, \mathrm{J}$ ). The sediment oxygen uptake rates observed at the outlet of the Rhône River are in the range of values reported in the literature. Morse and Rowe (1999) reported DOU rates decreasing from $50 \mathrm{mmol} \mathrm{O}_{2} \mathrm{~m}^{-2} \mathrm{~d}^{-1}$ near the Mississippi River mouth down to $2 \mathrm{mmol} \mathrm{O}_{2} \mathrm{~m}^{-2} \mathrm{~d}^{-1}$ further on the Gulf of Mexico shelf while Alongi (1995) measured fluxes ranging from 18$47 \mathrm{mmol} \mathrm{O}_{2} \mathrm{~m}^{-2} \mathrm{~d}^{-1}$ in the Gulf of Papua influenced by river inputs.

In our study, the distribution pattern over the shelf indicates an intense benthic mineralization close to the river mouth and a decrease of benthic degradation fluxes slower to the South-West than towards the South or the Southeast (Fig. 8). This feature matches the distribution footprint of the Rhône River inputs. Indeed, the South West has been proven to be a preferential direction for deposition of the terrestrial material in this area (Naudin et al., 1997; Calmet and Fernandez, 1990). Moreover, particles and organic matter tracers (radionuclides, carbon and nitrogen stable isotopes) from earlier studies clearly demonstrated a terrestrial origin of the sedimentary material nearby the river mouth (Aloisi et al., 1982; De Madron et al., 2000; Radakovitch et al., 1999b; Lansard et al., 2009; Tesi et al., 2007). The high OC and Chl $a$ contents observed in the prodelta area are associated with high $\mathrm{Chl} b$ and Pheoa contents; offshore stations presenting lower degraded material content and no $\mathrm{Chl} b$. This likely reflects inputs of terrestrial phytodetritus (Christensen, 1962) rather than local primary production stimulated by riverine nutrient inputs. Moreover, $\mathrm{Chl} b$ has been evidenced to be inversely correlated with labile carbon fraction in the area influenced by the Rhône River dilution plume (Alliot et al., 2003): the author evidence enrichment in labile organic matter mainly due to detritic organic matter of terrestrial origin. Therefore, although terrestrial material is generally supposed to be more refractory than marine inputs (Epping et al., 2002), this South West transect and the intense benthic mineralization at the river mouth seem to be directly dependant of the Rhône River inputs. This feature is consistent with the $\delta^{13} \mathrm{C}$ values of OM measured in Lansard et al. (2009). The terrestrial material is mainly deposited and processed in a restricted area corresponding to a radius of $8 \mathrm{~km}$ off the Rhône River mouth and high microbial degradation activity in this area is related both to the amount of material supplied and to its lability.

\subsubsection{Temporal variability of sediment oxygen uptake: non flood discharge rates conditions}

Our study indicates that under normal discharge rates, spatial pattern of OC oxidation in the prodelta is stable temporally on an annual basis: a similar distribution of DOU in the sediments was observed in spring, late summer or fall. Indeed, during our sampling cruises in April 2007, September 2007 and December 2008, the Rhône River discharge rates were around average and did not exceed $3000 \mathrm{~m}^{3} \mathrm{~s}^{-1}$ (the discharge rate at Arles for an annual flood being $4280 \mathrm{~m}^{3} \mathrm{~s}^{-1}$ ). Inputs during these cruises were therefore moderate, compared to the high discharge rates (liquid and particulate) delivered during the June 2008 cruise. Distribution of the DOU rates was similar during the three cruises and matches the one observed by Lansard et al. (2009) in June 2005. These authors performed their measurements under low discharge rates comparable to the one in April and September 2007 $\left(Q \sim 500 \mathrm{~m}^{3} \mathrm{~s}^{-1}\right)$ : the benthic degradation activity being driven by the Rhône River inputs (see above), it is therefore not surprising to observe similar DOU rates. Discharge rates in December 2008 were higher $\left(Q \sim 2000 \mathrm{~m}^{3} \mathrm{~s}^{-1}\right)$, explaining the differences in integrated SPM amount delivered during our cruise. This December 2008 cruise followed a 6-days annual flood that occurred on 1 November (see below). Nevertheless, one month after and under moderate flow rates, benthic degradation activity in the Rhône River prodelta displayed DOU values similar to low discharge rates. It can thus be concluded that, below the flood regime $\left(Q<3000 \mathrm{~m}^{3} \mathrm{~s}^{-1}\right)$, under what can be qualified as "normal" discharge rates conditions, the sediment oxygen uptake distribution displays a stable pattern over time, indicating potential stationary conditions.

\subsubsection{Temporal variability of sediment oxygen uptake: flood discharge rates conditions}

Our results (Fig. 7) show that the temporal variations of benthic mineralisation in the Rhône River prodelta are linked to extreme deposition events following flood conditions (June 2008). This annual flood delivered up to $5.4 \times 10^{6}$ tons of sediment in a 10 days period. This corresponds to $\sim 7.9 \times 10^{4}$ tons of $\mathrm{C}$ and an average flood deposit of $30 \mathrm{~cm}$, (Fig. 10). The Rhône River material settled near the river mouth (as much as $60 \mathrm{~cm}$ deposit at the nearest station) mainly in a south-westward direction (SW: $30-40 \mathrm{~cm}$ vs. SE: $13 \mathrm{~cm}$ ). Ulses et al. (2008) used a model coupling hydrodynamics and sediment transport in the Gulf of Lions for the flood of December 2003 and showed that the riverine material is deposited in the prodelta and mainly in front of the river mouth $(20 \mathrm{~cm}$ deposit). This flood is comparable to the June 2008 event: the water discharge rate was higher (up to $9346 \mathrm{~m}^{3} \mathrm{~s}^{-1}$ ) but the total sediment discharge was similar ( $\sim 4 \mathrm{Mt})$. Rapid and efficient sedimentation of the riverine material was also observed after the Po River flood in 2000 
(Miserocchi et al., 2007). The Rhône River prodelta is thus likely to act as an OC accumulation centre during flood periods. This idea is consistent with the high sedimentation rates between $48 \mathrm{~cm} \mathrm{y}^{-1}$ to $10 \mathrm{~cm} \mathrm{y}^{-1}$ observed in the area (Radakovitch et al., 1999a; Charmasson et al., 1998; Miralles et al., 2005) and the spatial distribution Pu isotopes, a tracer of river particles in sediments (Lansard et al., 2007).

The rapid deposition of large quantities of organic matter $(\mathrm{OM})$ in the prodelta during the June 2008 flood induced a sudden change in biogeochemical conditions in the sediment. Oxygen fluxes decreased by $20-30 \%$ at all stations close to the outlet of the Rhône River (Fig. 7) and deeper oxygen penetration depth were observed a few days after the flood deposit. This is in agreement with a study of the Po River flood in 2000 (Dell'Anno et al., 2008) who observed a decrease of OM degradation rates in coastal sediments from the Northern Adriatic. Similarly, a drop in benthic community respiration was observed after a flood in south-eastern Australian rivers (Rees et al., 2005) and in the Australian subtropical Brunswick estuary (Eyre et al., 2006). Authors argued that the flood scoured the sediment, leaving a poor carbon content layer to be degraded. In our study, the flood in June 2008 did not erode the sediment as evidenced by the presence of an ochre mud below the flood deposit (Fig. 10). Alternatively, the flood brought a low OC content layer, poor in phytodetritus and labile organic matter which resulted in a decrease of OM mineralization rate. Indeed, surface sediments of stations A, B, K, L, C located near the river mouth presented lower OC and Chl $a$ contents in June 2008 compared to the "non-flood" cruises (OC: $1.1 \pm 0.1 \%$ vs. $1.5 \pm 0.2 \%$; Chl $a$ : 3 vs. $10 \mu \mathrm{g} \mathrm{g}^{-1}$ d.w.; Fig. 10; Table 1). In addition the bio-available compounds contents constituted by the sum of carbohydrates, lipids and proteins were considerably lower in the June 2008 surface sediments indicating also a poorly degradable material (4 vs. $7 \mathrm{mg} \mathrm{g}^{-1}$ d.w.; R. Buscail, personal communication, 2009). The Suspended Particulate Matter (SPM) of the Rhône River during the June 2008 flood event had a low OC content $(0.8 \%)$ with depleted $\Delta^{14} \mathrm{C}$ and enriched $\delta^{13} \mathrm{C}$ signatures $\left(\Delta^{14} \mathrm{C}=-500 \%\right.$ o, $\delta^{13} \mathrm{C}=-25.8 \%$ ) , compared to the normal hydrological regimes where POC content in the river is $3.5 \%$, with $\Delta^{14} \mathrm{C} \sim 100 \%$ and $\delta^{13} \mathrm{C} \sim-27 \%$ o signatures (Cathalot et al., 2010). Linked to a Western Alps related flood which eroded river banks and cultivated land, the flood has certainly brought large quantities of soil carbon as evidenced by Tesi et al. (2008) at the Po River outlet in October 2000. The low $\Delta^{14} \mathrm{C}$ signal and slightly enriched $\delta^{13} \mathrm{C}(-25.8 \%$ ) values indicate a mixture of old soil-derived OC, with minor contribution of vascular plants and riverine and estuarine phytoplankton, as indicated by the low $\mathrm{Chl} a$ and $\mathrm{Chl} b$ content observed in the flood deposit. Mean diameter of surface sediments at the river outlet (stations A and $\mathrm{K}$ ) dropped from $37.40 \mu \mathrm{m}$ to $6 \mu \mathrm{m}$ shifting from silt to clay like sediments (cf. Table 1) in agreement with the soil origin of the particles. An important part of the organic material from the flood may be associ- ated with clay and thus protected from bacterial degradation (Mayer, 1994; Keil et al., 1994) which could reduce mineralisation of organic matter in the sediments after this type of flood. These results indicate that flood events may bring soil $\mathrm{OM}$ in large quantities but do not imply an increase in the sediment recycling despite the large quantities of carbon delivered. The prodelta thus acts as a depocentre for terrestrial OM inputs.

During our study, we were able to follow the flood event over 6 months with sediment cores and measure the DOU rates at the start of the flood and 6 months after. This gave us valuable insights on the dynamics and pathways involved in the relaxation of the sediment system linked to mineralisation. The large June 2008 flood obviously generated a transient state in the sediment compared to April and September 2007 distributions. Indeed, DOU rates in the deposit zone were significantly lower after the flood. Besides, the redox profile performed in the June 2008 deposit clearly indicates the location of a former interface below the newly deposited material. Dell'Anno et al. (2008) noticed that after the immediate decrease consecutive to the deposition of flood material, sediment oxygen uptake rates rose up again, as a consequence of the system relaxation. The return to stationary conditions results from a combination of all biogeochemical processes taking place in the sedimentary column: a new interface is forming, all chemical species are diffusing, marine bacteria are colonizing the new sediment and consuming the organic carbon (Deflandre et al., 2002; Mucci et al., 2003; Sundby, 2006). Erosion of the $30 \mathrm{~cm}$ soft deposit in the prodelta is certainly limited since the deposited layer, sampled $2.7 \mathrm{~km}$ south from the Rhône River mouth, remains identical until at least October 2008 (Fig. 10). This is consistent with the hydrodynamic conditions during this period: low wave significant heights $(<4 \mathrm{~m})$ and low discharge rates. A slight compaction (from $30 \mathrm{~cm}$ thickness to $\sim 25 \mathrm{~cm}$ ) is visible with no significant organic carbon decrease. New sedimentation of river particles also occurred since in December only $18 \mathrm{~cm}$ of this soft mud from the June 2008 flood remains and a new deposit is visible mainly due to further November flood, which brought organic-rich material $(6 \%)$. This sudden burial of OC underlines the transient nature of these prodelta environments during flood deposits. Hence, the sediment $\mathrm{O}_{2}$ distribution, and therefore DOU rates, is not strickly related to carbon degradation in these transient environments. Successive depositions of OM material via flood events switch the systems from stationary conditions (under normal discharge rates) with a tight coupling between oxygen consumption and carbon mineralization, to transient flood conditions with uncoupled $\mathrm{OC}$ and $\mathrm{O}_{2}$ cycles (Aller, 1998).

Six months after the flood event, oxygen fluxes in the prodelta had increased and had reached back their initial values before the flood. At the same time, the Southwest gradient of oxygen consumption was re-established (Fig. 9). Oxygen consumption in station A sediments during the flood 
was around $9 \times 10^{-2} \mathrm{mmol} \mathrm{O}_{2} \mathrm{~L}^{-1} \mathrm{~h}^{-1}$. Considering a mean oxygen concentration among the sediment in the new deposit of $300 \mu \mathrm{mol} \mathrm{L}^{-1}$, it would only take $3.3 \mathrm{~h}$ for the whole oxygen trapped in porewaters during mud deposition to be consumed, indicating that consumption of oxygen at the observed rates can significantly contribute to the relaxation of the system. Oxygen consumption after the flood event results from the re-establishment of the bacterial community and the re-establishment of the redox front within the flood deposit. Our current dataset do not allow us to discriminate which process dominates but gives insights on the time-scales involved. Indeed, the redox profile in the June 2008 flood deposit indicates that only a few days after the beginning of the flood, the redox front was already settled at $10 \mathrm{~cm}$ below the SWI. We can thus assume that the time scales involved for the return to stationary conditions are short. Moreover, our observations in December 2008 also suggest a dynamic and rapid system. Indeed, DOU rates in the prodelta sediments of the prodelta already showed similar to low discharge rates conditions, only one month after an annual flood. This November flood was different from the June flood with $\sim 11$ times less particles, but just $\sim 6$ times less carbon delivered, and $\mathrm{OC}$ contents above 5\%. The response induced to the sediment might therefore have been different. Nevertheless, it still indicates that sediments off the Rhône River are reactive enough to display stationary conditions one month after a flood event. This time scale is in agreement with flood event studies in other coastal environments which evidenced relaxation time scales around weeks (Bentley and Nittrouer, 2003; Eyre and Ferguson, 2006; Eyre and Twigg, 1997; Deflandre et al., 2002). Re-establishment of bacterial community could be one of the driving mechanisms as the time scales involved are also in the order of weeks (Boer et al., 2009; Aller and Aller, 2004), in agreement with our data.

Therefore, our study indicates the relative importance of the mineralization reaction processes and the reestablishment of the microbial community, and their rapid timescale (hours to weeks). It appears that the dynamics of the Rhône River inputs and the sedimentation processes associated are key factor for carbon mineralization processes in the sediment. Our data suggest that the response of the benthic degradation system of the Rhône River prodelta to flood inputs involves rapid processes ranging from weeks to months.

\section{Conclusions}

This paper describes the temporal variability of organic matter mineralization in sediments from the Rhône River prodelta and Gulf of Lions adjacent shelf using oxygen demand as a proxy.

The results indicate that the spatial pattern of decreasing oxygen demand with distance from the river mouth is persistent over different seasons under "normal discharge conditions" i.e. out of the flood periods. River organic inputs are concentrated and largely mineralized in a zone located around $8 \mathrm{~km}$ from the river outlet. This large mineralization is linked to substantial inputs of reactive terrestrial organic matter indicated by the presence of $\mathrm{Chl} a$ and $\mathrm{Chl} b$ at the river outlet.

During one major flood deposition (average of $30 \mathrm{~cm}$ ), the oxygen demand in the prodelta decreases by $20-30 \%$, whereas the shelf is not affected. For the flood encountered in June 2008, a realistic scenario is the deposition of a large quantity of low reactivity material originating from soils in the drainage basin near the outlet of the Rhône River. Transient processes are involved after a flood deposit: bacterial respiration, reduction and oxidation cycles, deposition of new organic material from the river, which create a rapid relaxation of the oxygen distribution towards its initial state (weeks to months). Oxygen demand in flood impacted sediment is decoupled from carbon mineralization: succession of flood deposits and transient conditions promote burial of large quantities of $\mathrm{OM}$ and tend to reduce the efficiency of benthic carbon degradation. The extent of this decoupling depends on the quantity and the lability of the carbon delivered by the flood (soil OM vs. fresh phyto-detritus), and is therefore directly dependant on the type of flood event.

Acknowledgements. We thank the captains and crews of the R. V. Tethys II for their help in sea work during the four sea expeditions of this project. We would like to thank B. Bombled, B. Lansard, M. Desmalades, K. Escoubeyrou, G. Vetion, and B. Rivière for their work and technical support during the cruises and their help during laboratory analyses. F. Lantoine provided expertise in pigment analysis.

We thank Claire Powell for proofreading our article and correcting improper English expressions.

In situ wave height measurements were extracted from the French national database CANDHIS and performed within the framework between the Direction Régionale de l'Environnement, de l'Aménagement et du Logement Languedoc-Roussillon, the Port Autonome de Marseille et the CETMEF.

Discharge and SPM data have been achieved in the courtesy of the CNR and the SORA in the workframe of a convention with IRSN in the EXTREMA ANR project.

This work was supported by the French National Research Agency, programme "Vulnérabilités: Milieux et Climat", under the grant no. ANR-06-VULN-001 to the CHACCRA project, the French INSU-EC2CO program RiOMar.fr, and the CEA. This is a LSCE contribution 4178 .

Edited by: A. V. Borges

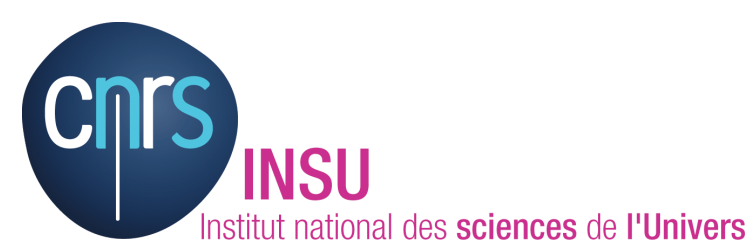

The publication of this article is financed by CNRS-INSU. 


\section{References}

Accornero, A., Picon, P., de Bovee, F., Charriere, B., and Buscail, R.: Organic carbon budget at the sediment-water interface on the Gulf of Lions continental margin, Cont. Shelf Res., 23, 79-92, 2003.

Aller, J. Y. and Aller, R. C.: Physical disturbance creates bacterial dominance of benthic biological communities in tropical deltaic environments of the Gulf of Papua, Cont. Shelf Res., 24, 23952416, 2004.

Aller, R. C.: Mobile deltaic and continental shelf muds as suboxic, fluidized bed reactors, Mar. Chem., 61, 143-155, 1998.

Alliot, E., Younes, W. A. N., Romano, J. C., Rebouillon, P., and Masse, H.: Biogeochemical impact of a dilution plume (Rhône River) on coastal sediments: Comparison between a surface water survey (1996-2000) and sediment composition, Estuar. Coast. Shelf Sci., 57, 357-367, 2003.

Allison, M. A., Kineke, G. C., Gordon, E. S., and Goni, M. A.: Development and reworking of a seasonal flood deposit on the inner continental shelf off the Atchafalaya River, Cont. Shelf Res., 20, 2267-2294, 2000.

Aloisi, J. C., Cambon, J. P., Carbonne, J., Cauwet, G., Millot, C., Monaco, A., and Pauc, H.: Origin and role of the bottom nepheloid layer in the tranfer of particles into the marine environment - application to the Gulf of Lions, Oceanol. Acta, 5, 481-491, 1982.

Alongi, D. M.: Decomposition and recycling of organic matter in muds of the Gulf of Papua, northern coral sea, Cont. Shelf Res., 15, 1319-1337, 1995.

Andrews, D. and Bennett, A.: Measurements of diffusivity near the sediment-water interface with a fine-scale resistivity probe, Geochim. Cosmochim. Acta, 45, 2169-2175, 1981.

Antonelli, C., Eyrolle, F., Rolland, B., Provansal, M., and Sabatier, F.: Suspended sediment and Cs-137 fluxes during the exceptional December 2003 flood in the Rhône River, southeast France, Geomorphology, 95, 350-360, doi:10.1016/j.geomorph.2007.06.007, 2008.

Bentley, S. J. and Nittrouer, C. A.: Emplacement, modification, and preservation of event strata on a flood-dominated continental shelf: Eel shelf, Northern California, Cont. Shelf Res., 23, 1465-1493, doi:10.1016/j.csr.2003.08.005, 2003.

Berg, P., Risgaard-Petersen, N., and Rysgaard, S.: Interpretation of measured concentration profiles in sediment pore water, Limnol. Oceanogr., 43, 1500-1510, 1998.

Berner, R. A.: Early diagenesis: A theoretical approach, Princeton series in geochemistry, edited by: Princeton, N. J., Princeton University Press, Princeton, 241 pp., 1980.

Blair, N. E., Leithold, E. L., and Aller, R. C.: From bedrock to burial: The evolution of particulate organic carbon across coupled watershed-continental margin systems, Mar. Chem., 92, 141-156, 2004.

Böer, S. I., Arnosti, C., van Beusekom, J. E. E., and Boetius, A.: Temporal variations in microbial activities and carbon turnover in subtidal sandy sediments, Biogeosciences, 6, 1149-1165, 2009, http://www.biogeosciences.net/6/1149/2009/.

Brand, A., Dinkel, C., and Wehrli, B.: Influence of the diffusive boundary layer on solute dynamics in the sediments of a seiche-driven lake: A model study, J. Geophys. Res.-Biogeosci., 114(12), G01010 doi:10.1029/2008jg000755, 2009.

Broecker, W. S. and Peng, T. H.: Gas-exchange rates between air and sea, Tellus, 26, 21-35, 1974.

Burdige, D. J.: Burial of terrestrial organic matter in marine sediments: A re-assessment, Global Biogeochem. Cy., 19, GB4011, doi:10.1029/2004GB002368, 2005.

Cai, W. J., Reimers, C. E., and Shaw, T.: Microelectrode studies of organic carbon degradation and calcite dissolution at a California continental rise site, Geochim. Cosmochim. Acta, 59, 497-511, 1995.

Calmet, D. and Fernandez, J.-M.: Caesium distribution in Northwest Mediterranean seawater, suspended particles and sediments, Cont. Shelf Res., 10, 895-913, 1990.

Cathalot, C., Rabouille, C., Tisnerat-Laborde, N., Buscail, R., Kerherve, P., and Gontier, G.: Sources and fate of particulate organic carbon export from the Rhne River in the Mediterranean Sea: combined use of $\triangle 14 \mathrm{C}$ and $\delta 13 \mathrm{C}$, in preparation, 2010.

Cauwet, G., Gadel, F., de Souza Sierra, M. M., Donard, O., and Ewald, M.: Contribution of the rhône river to organic carbon inputs to the Northwestern Mediterranean Sea, Cont. Shelf Res., 10, 1025-1037, 1990.

Charmasson, S., Bouisset, P., Radakovitch, O., Pruchon, A. S., and Arnaud, M.: Long-core profiles of cs-137, cs-134, co-60 and pb210 in sediment near the Rhône River (Northwestern Mediterranean Sea), Estuaries, 21, 367-378, 1998.

Christensen, T.: Alger, in: Botanik ii. Systematik botanik, edited by: Bocher, T. W., Lange, M., and Sorensen, T., Munksgaard, Copenhagen, 1-178, 1962.

Copin-Montegut, C.: Alkalinity and carbon budgets in the Mediterranean Sea, Global Biogeochem. Cy., 7, 915-925, 1993.

Dagg, M., Benner, R., Lohrenz, S., and Lawrence, D.: Transformation of dissolved and particulate materials on continental shelves influenced by large rivers: Plume processes, Cont. Shelf Res., 24, 833-858, 2004.

Darnaude, A. M., Salen-Picard, C., and Harmelin-Vivien, M. L.: Depth variation in terrestrial particulate organic matter exploitation by marine coastal benthic communities off the Rhône River delta (NW Mediterranean), Mar. Ecol.-Prog. Ser., 275, 47-57, 2004.

de Madron, X. D., Radakovitch, O., Heussner, S., Loye-Pilot, M. D., and Monaco, A.: Role of the climatological and current variability on shelf-slope exchanges of particulate matter: Evidence from the Rhône continental margin (NW Mediterranean), DeepSea Res. I, 46, 1513-1538, 1999.

De Madron, X. D., Abassi, A., Heussner, S., Monaco, A., Aloisi, J. C., Radakovitch, O., Giresse, P., Buscail, R., and Kerherve, P.: Particulate matter and organic carbon budgets for the Gulf of Lions (NW Mediterranean), Oceanol. Acta, 23, 717-730, 2000.

de Madron, X. D., Denis, L., Diaz, F., Garcia, N., Guieu, C., Grenz, C., Loye-Pilot, M. D., Ludwig, W., Moutin, T., Raimbault, P., and Ridame, C.: Nutrients and carbon budgets for the Gulf of Lion during the Moogli cruises, Oceanol. Acta, 26, 421-433, 2003.

Deflandre, B., Mucci, A., Gagne, J. P., Guignard, C., and Sundby, B.: Early diagenetic processes in coastal marine sediments disturbed by a catastrophic sedimentation event, Geochim. Cosmochim. Acta, 66, 2547-2558, 2002.

Dell'Anno, A., Pusceddu, A., Langone, L., and Danovaro, R.: Biochemical composition and early diagenesis of organic matter in coastal sediments of the NW Adriatic Sea influenced by riverine inputs, Chem. Ecol., 24, 75-85, 
doi:10.1080/02757540701814580, 2008.

Denis, L., Grenz, C., Alliot, E., and Rodier, M.: Temporal variability in dissolved inorganic nitrogen fluxes at the sediment-water interface and related annual budget on a continental shelf (NW Mediterranean), Oceanol. Acta, 24, 85-97, 2001.

Epping, E., van der Zee, C., Soetaert, K., and Helder, W.: On the oxidation and burial of organic carbon in sediments of the Iberian margin and Nazare canyon (NE Atlantic), Prog. Oceanogr., 52, 399-431, 2002.

Eyre, B. D. and Ferguson, A. J. P.: Impact of a flood event on benthic and pelagic coupling in a sub-tropical east Australian estuary (Brunswick), Estuar. Coast. Shelf Sci., 66, 111-122, 2006.

Friedrichs, C. T. and Wright, L. D.: Gravity-driven sediment transport on the continental shelf - implications for equilibrium profiles near river mouths, Coast. Eng., 51, 795-811, doi:10.1016/j.coastaleng.2004.07.010, 2004.

Froelich, P. N., Klinkhammer, G. P., Bender, M. L., Luedtke, N. A., Heath, G. R., Cullen, D., Dauphin, P., Hammond, D., Hartman, B., and Maynard, V.: Early oxidation of organic-matter in pelagic sediments of the eastern equatorial atlantic - suboxic diagenesis, Geochim. Cosmochim. Acta, 43, 1075-1090, 1979.

Galy, V., France-Lanord, C., Beyssac, O., Faure, P., Kudrass, H., and Palhol, F.: Efficient organic carbon burial in the Bengal fan sustained by the Himalayan erosional system, Nature, 450, 407410, 2007.

Gattuso, J. P., Frankignoulle, M., and Wollast, R.: Carbon and carbonate metabolism in coastal aquatic ecosystems, Annual Review of Ecology and Systematics, 29, 405-434, 1998.

Glud, R. N., Holby, O., Hoffmann, F., and Canfield, D. E.: Benthic mineralization and exchange in Arctic sediments (Svalbard, Norway), Mar. Ecol.-Prog. Ser., 173, 237-251, 1998.

Glud, R. N., Risgaard-Petersen, N., Thamdrup, B., Fossing, H., and Rysgaard, S.: Benthic carbon mineralization in a high-arctic sound (Young Sound, NE Greenland), Mar. Ecol.-Prog. Ser., 206, 59-71, 2000.

Glud, R. N., Gundersen, J. K., Roy, H., and Jorgensen, B. B.: Seasonal dynamics of benthic o-2 uptake in a semienclosed bay: Importance of diffusion and faunal activity, Limnol. Oceanogr., 48, 1265-1276, 2003.

Glud, R. N., Berg, P., Fossing, H., and Jorgensen, B. B.: Effect of the diffusive boundary layer on benthic mineralization and o-2 distribution: A theoretical model analysis, Limnol. Oceanogr., 52, 547-557, 2007.

Grasshoff, K., Ehrhardt, M., and Kremling, K.: Methods of seawater analysis, Verlag Chemie, 419 pp., 1983.

Hedges, J. I.: Global biogeochemical cycles: Progress and problems, Mar. Chem., 39, 67-93, 1992.

Hedges, J. I. and Keil, R. G.: Sedimentary organic-matter preservation - an assessment and speculative synthesis, Mar. Chem., 49, 81-115, 1995.

Hedges, J. I., Keil, R. G., and Benner, R.: What happens to terrestrial organic matter in the ocean?, Org. Geochem., 27, 195-212, 1997.

Hopkinson, C. S., Giblin, A. E., and Tucker, J.: Benthic metabolism and nutrient regeneration on the continental shelf of Eastern Massachusetts, USA, Mar. Ecol.-Prog. Ser., 224, 1-19, 2001.

Hulth, S., Tengberg, A., Landen, A., and Hall, P. O. J.: Mineralization and burial of organic carbon in sediments of the Southern Weddell Sea (Antarctica), Deep-Sea Res. I, 44, 955-981, 1997.
Iversen, N. and Jorgensen, B. B.: Diffusion-coefficients of sulfate and methane in marine-sediments - influence of porosity, Geochim. Cosmochim. Acta, 57, 571-578, 1993.

Jorgensen, B. B. and Revsbech, N. P.: Diffusive boundarylayers and the oxygen-uptake of sediments and detritus, Limnol. Oceanogr., 30, 111-122, 1985.

Keil, R. G., Montlucon, D. B., Prahl, F. G., and Hedges, J. I.: Sorptive preservation of labile organic matter in marine sediments, Nature, 370, 549-552, 1994.

Kelly-Gerreyn, B. A., Hydes, D. J., and Waniek, J. J.: Control of the diffusive boundary layer on benthic fluxes: A model study, Mar. Ecol.-Prog. Ser., 292, 61-74, 2005.

Lansard, B., Rabouille, C., and Massias, D.: Variability in benthic oxygen fluxes during the winter-spring transition in coastal sediments: An estimation by in situ micro-electrodes and laboratory mini-electrodes, Oceanol. Acta, 26, 269-279, 2003.

Lansard, B., Charmasson, S., Gasco, C., Anton, M. P., Grenz, C., and Arnaud, M.: Spatial and temporal variations of plutonium isotopes (Pu-238 and $\mathrm{Pu}-239, \mathrm{Pu}-240)$ in sediments off the Rhône River mouth (NW Mediterranean), Sci. Total Environ., 376, 215-227, doi:10.1016/j.scitotenv.2007.01.069, 2007.

Lansard, B., Rabouille, C., Denis, L., and Grenz, C.: Benthic remineralization at the land-ocean interface: A case study of the Rhône River (NW Mediterranean Sea), Estuar. Coast. Shelf Sci., 81, 544-554, doi:10.1016/j.ecss.2008.11.025, 2009.

Leithold, E. L. and Hope, R. S.: Deposition and modification of a flood layer on the Northern California shelf: Lessons from and about the fate of terrestrial particulate organic carbon, Mar. Geol., 154, 183-195, 1999.

Lisitsyn, A. P.: The marginal filter of the ocean, Oceanology, 34, 671-682, 1995.

Lorke, A., Muller, B., Maerki, M., and Wuest, A.: Breathing sediments: The control of diffusive transport across the sedimentwater interface by periodic boundary-layer turbulence, Limnol. Oceanogr., 48, 2077-2085, 2003.

Mayer, L. M.: Surface area control of organic carbon accumulation in continental shelf sediments, Geochim. Cosmochim. Acta, 58, 1271-1284, 1994.

McKee, B. A., Aller, R. C., Allison, M. A., Bianchi, T. S., and Kineke, G. C.: Transport and transformation of dissolved and particulate materials on continental margins influenced by major rivers: Benthic boundary layer and seabed processes, Cont. Shelf Res., 24, 899-926, 2004.

Meybeck, M.: Carbon, nitrogen, and phosphorus transport by world rivers, Am. J. Sci., 282, 401-450, 1982.

Millot, C.: The Gulf of Lions hydrodynamics, Cont. Shelf Res., 10, 885-894, 1990.

Miralles, J., Radakovitch, O., and Aloisi, J. C.: Pb-210 sedimentation rates from the Northwestern Mediterranean margin, Mar. Geol., 216, 155-167, 2005.

Miserocchi, S., Langone, L., and Tesi, T.: Content and isotopic composition of organic carbon within a flood layer in the Po River prodelta (Adriatic Sea), Cont. Shelf Res., 27, 338-358, 2007.

Monaco, A., de Madron, X. D., Radakovitch, O., Heussner, S., and Carbonne, J.: Origin and variability of downward biogeochemical fluxes on the Rhône continental margin (NW Mediterranean), Deep-Sea Res. I, 46, 1483-1511, 1999.

Morse, J. W. and Rowe, G. T.: Benthic biogeochemistry beneath 
the Mississippi River plume, Estuaries, 22, 206-214, 1999.

Mucci, A., Boudreau, B., and Guignard, C.: Diagenetic mobility of trace elements in sediments covered by a flash flood deposit: Mn, Fe and As, Appl. Geochem., 18, 1011-1026, 2003.

Naudin, J. J., Cauwet, G., ChretiennotDinet, M. J., Deniaux, B., Devenon, J. L., and Pauc, H.: River discharge and wind influence upon particulate transfer at the land-ocean interaction: Case study of the Rhône River plume, Estuar. Coast. Shelf Sci., 45, 303-316, 1997.

Neveux, J. and Lantoine, F.: Spectrofluorometric assay of chlorophylls and pheopigments using the least-squares approximation technique, Deep-Sea Res. I, 40, 1747-1765, 1993.

Pont, D., Simonnet, J. P., and Walter, A. V.: Medium-term changes in suspended sediment delivery to the ocean: Consequences of catchment heterogeneity and river management (Rhône River, France), Estuar. Coast. Shelf Sci., 54, 1-18, 2002.

Rabouille, C., Denis, L., Dedieu, K., Stora, G., Lansard, B., and Grenz, C.: Oxygen demand in coastal marine sediments: Comparing in situ microelectrodes and laboratory core incubations, J. Exp. Mar. Biol. Ecol., 285, 49-69, 2003.

Radakovitch, O., Charmasson, S., Arnaud, M., and Bouisset, P.: $\mathrm{Pb}-210$ and caesium accumulation in the Rhône delta sediments, Estuar. Coast. Shelf Sci., 48, 77-92, 1999a.

Radakovitch, O., Cherry, R. D., and Heussner, S.: Pb-210 and po210: Tracers of particle transfer on the Rhône continental margin (NW Mediterranean), Deep-Sea Res. I, 46, 1539-1563, 1999b.

Rees, G. N., Bowen, P. M., and Watson, G. O.: Variability in benthic respiration in three southeastern australian lowland rivers, River Res. Applic., 21, 1147-1156, 2005.

Reimers, C. E., Jahnke, R. A., and McCorkle, D. C.: Carbon fluxes and burial rates over the continental slope and rise off central California with implications for the global carbon cycle, Global Biogeochem. Cy., 6, 199-224, doi:10.1029/92GB00105, 1992.

Revsbech, N. P.: An oxygen microsensor with a guard cathode, Limnol. Oceanogr., 34, 474-478, 1989.

Roy, H., Huttel, M., and Jorgensen, B. B.: The role of small-scale sediment topography for oxygen flux across the diffusive boundary layer, Limnol. Oceanogr., 47, 837-847, 2002.
Salen-Picard, C. and Arlhac, D.: Long-term changes in a Mediterranean benthic community: Relationships between the polychaete assemblages and hydrological variations of the Rhône River, Estuaries, 25, 1121-1130, 2002.

Sempere, R., Charriere, B., Van Wambeke, F., and Cauwet, G.: Carbon inputs of the Rhône River to the Mediterranean Sea: Biogeochemical implications, Global Biogeochem. Cy., 14, 669-681, 2000.

Smith, S. V. and Hollibaugh, J. T.: Coastal metabolism and the oceanic organic-carbon balance, Rev. Geophys., 31, 75-89, 1993.

Sommerfield, C. K. and Nittrouer, C. A.: Modern accumulation rates and a sediment budget for the Eel shelf: A flood-dominated depositional environment, Mar. Geol., 154, 227-241, 1999.

Sundby, B.: Transient state diagenesis in continental margin muds, Mar. Chem., 102, 2-12, 2006.

Sweerts, J., Stlouis, V., and Cappenberg, T. E.: Oxygen concentration profiles and exchange in sediment cores with circulated overlying water, Freshwater Biol., 21, 401-409, 1989.

Tesi, T., Miserocchi, S., Goni, M. A., and Langone, L.: Source, transport and fate of terrestrial organic carbon on the Western Mediterranean Sea, Gulf of Lions, France, Mar. Chem., 105, 101-117, 2007.

Tesi, T., Langone, L., Goni, M. A., Miserocchi, S., and Bertasi, F.: Changes in the composition of organic matter from prodeltaic sediments after a large flood event (Po River, Italy), Geochim. Cosmochim. Acta, 72, 2100-2114, doi:10.1016/j.gca.2008.02.005, 2008.

Ulses, C., Estournel, C., de Madron, X. D., and Palanques, A.: Suspended sediment transport in the Gulf of Lions (NW Mediterranean): Impact of extreme storms and floods, Cont. Shelf Res., 28, 2048-2070, doi:10.1016/j.csr.2008.01.015, 2008.

Wheatcroft, R. A. and Borgeld, J. C.: Oceanic flood deposits on the Northern California shelf: Large-scale distribution and smallscale physical properties, Cont. Shelf Res., 20, 2163-2190, 2000. 